\title{
Safety Evaluation of New Polymer Materials Proposed for Relining Drinking Water Pipes in the City of Milano
}

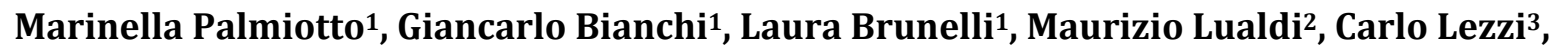 \\ Angela Manenti ${ }^{4}$, Enrico Davoli ${ }^{*}$ \\ ${ }^{1}$ Department of Environmental Health Sciences, IRCCS Istituto di Ricerche Farmacologiche Mario Negri, Milano, \\ Italy \\ ${ }^{2}$ Politecnico of Milano, Milano, Italy \\ ${ }^{3}$ Beca Engineering S.r.I., Milano, Italy \\ ${ }^{4}$ Metropolitana Milanese S.p.A., Milano, Italy \\ Email: "enrico.davoli@marionegri.it
}

Received 22 September 2015; accepted 27 December 2015; published 30 December 2015

Copyright $(2015$ by authors and Scientific Research Publishing Inc.

This work is licensed under the Creative Commons Attribution International License (CC BY).

http://creativecommons.org/licenses/by/4.0/

(c) (i) Open Access

\begin{abstract}
Relining is a trenchless technology of recoating the inside walls of damaged water pipes using composite materials. In the Safe Pipe project, co-financed by Regione Lombardia, alternative polymeric materials for relining the drinking water distribution system of the city of Milan have been developed. Relining polymers have been evaluated for their toxicity. The identification of product impurities was performed by HPLC/HRMS and GC/MS analysis and safety evaluation was conducted applying toxicity data, when available, or applying QSAR models. Results showed low level of toxic substances in polymerized resins and in water samples in a migration/leaching test performed in a field experiment.
\end{abstract}

\section{Keywords}

Contaminants Identification, Drinking Water Quality, Risk Assessment

\section{Introduction}

The integrated water service for the city of Milan captures, purifies and distributes drinking water, collects sewage and manages its treatment before releasing it into the environment. In the city of Milan, the drinking water

*Corresponding author.

How to cite this paper: Palmiotto, M., Bianchi, G., Brunelli, L., Lualdi, M., Lezzi, C., Manenti, A. and Davoli, E. (2015) Safety Evaluation of New Polymer Materials Proposed for Relining Drinking Water Pipes in the City of Milano. International Journal of Analytical Mass Spectrometry and Chromatography, 3, 63-79. http://dx.doi.org/10.4236/ijamsc.2015.34008 
is drawn from the aquifers at a depth ranging from 30 to 300 meters and, after potabilization and monitoring process, the water is distributed throughout the city with a water supply network of about $2360 \mathrm{~km}$. The distribution system consists of about 230 million $\mathrm{m}^{3}$ of delivered drinking water per year. Corrosion of pipes can produce leaks and loss of efficiency in the drinking water distribution system with significant economic and environmental consequences. It is estimated that the loss of drinking water in Milan is about $10 \%$ [1]. It is clear that significant economic and environmental consequences are due to this problem.

To reduce the water loss, the piping network is systematically monitored, replacing or repairing damaged pipe sections. Relining is an increasingly used method for recoating the inside of damaged or old water pipes that allows an in-place pipe restoration. Here, a stocking glass fiber, impregnated with a liquid formulation, is introduced, expanded and polymerized inside the host pipe. The formulation is formed by a photoinitiator, monomers and oligomers. The monomers and oligomers are generally derivatives of acrylate/methacrylate compounds, containing polyurethanes, polyesters or polyethers. The type of oligomers and additives, such as UV stabilizers, solvents, give specific mechanical properties to the finished product. The photoinitiator, after irradiation by UV light, fragments into free radicals that reacts converting the formulation into a solid cured film.

There are few studies about release of chemicals in water from relined pipes. Recently migration of Bisphenol A (BPA), an endocrine disruptor, in drinking water from relined pipes, has raised many concern [2] [3]. In this project, Politecnico of Milano and Beca Italia have developed new technologies and alternative materials for the possible relining of the drinking water distribution system in the city of Milano. A ground penetrating radar (GPR) system to conduct three-dimensional survey for mapping underground utilities has been developed to detect the utilities regardless of the material and geometry.

The aim of this work was, as a first step, evaluating the toxicity of these materials using all information contained in the material safety data sheets (MSDS) and those available in the scientific literature and, for components were no toxicological information are available, using QSAR (Quantitative Structure-Activity Relationship) models. The use of QSAR models is an important example of "in silico" methods. QSAR are computer-based models that correlate the properties and molecular structure of a chemical with its biological effect on human. The correlation can then be used in the prediction and assessment of toxicity of substances where experimental data are missing. They aim at establishing, if exists, the relationship between structural-derived properties of chemicals and their properties, such as toxicity.

A second step was focused on trace analysis of undeclared components released in water and their toxicological evaluation. All materials have been analyzed to identify impurities released before and after polymerization, undisclosed components or impurities that are undeclared by the producer because of their low concentration. Volatile organic compounds (VOCs) and Bisphenol A (BPA) have been also analyzed specifically by mass spectrometry.

Human health risk has been characterized combining the toxicity data, where available, with the data obtained from compounds identified by mass spectrometry, using Quantitative Structure-Activity Relationship (QSAR) models for components with no toxicological information available, to assess human health risk of the new proposed materials.

\section{Experimental}

The materials investigated as relining polymers included acrylate resins, epoxy acrylate, vinyl ester acrylate, urethane acrylate, hydroxyethyl methacrylate, alchidic and polyester resins and their formulations as mixtures, before and after photo-polymerization process. A preliminary evaluation of proposed materials has been made considering the toxicological information of chemicals reported in the MSDS and those available in TOXNET (TOXicological data NETwork, www.toxnet.nlm.nih.gov) database. TOXNET includes more databases that cover environmental health, occupational safety and health, risk assessment and toxicology and are: ChemIDplus (Chemical Identification/Dictionary), HSDB (Hazardous Substances Data Bank), TOXLINE (Toxicology Literature Online), CCRIS (Chemical Carcinogenesis Risk Information System), GENETOX (Genetic Toxicology Data), IRIS (Integrated Risk Information), DART (Developmental Toxicology Literature) and Haz-Map (Occupational Exposure to Hazardous Agents).

QSAR models that have been used in this study are available through the application of the software VegaNIC. The software works by inserting a simplified representation of the structure of the compound to be evaluated, called SMILE (Simplified Molecular Input Line Entry System). The SMILES of the compounds have been ob- 
tained from the ChemIDplus database of TOXNET. The end-points that have been evaluated with the correspondent QSAR model are those listed in Table 1.

The mutagenicity is calculated in reference to Salmonella typhimurium (Ames test), the bioconcentration factor BCF is calculated for the fish. The reliability of the prediction is assessed by a Global ADI (Applicability Domain Index) that has values from 0 (worst case) to 1 (best case). The Global ADI is calculated by grouping several other indices based on the calculation of the most similar compounds found in the training and test set of the model, considering molecule's fingerprint and structural aspects (count of atoms, rings and relevant fragments).

The analytical characterization of polar, non volatile impurities has been performed by HPLC coupled with high-resolution mass spectrometry. Samples were dissolved in methanol and directly analyzed by LC-MS/MS, using an LTQ Orbitrap XL ${ }^{\mathrm{TM}}$ (Thermo Scientific), interfaced with a 1200 series capillary pump (Agilent). The MS instrument was operated in positive (POS) and negative (NEG) ionization modes. MS conditions were: source DESI Omni Spray (Prosolia, Indianapolis, IN) used in nanospray mode with positive and negative ion modes; ion spray voltage $2100 \mathrm{~V}$; capillary temperature $220^{\circ} \mathrm{C}$; capillary voltage, $42 \mathrm{~V}$. MS spectra (80 - 2000 $\mathrm{m} / \mathrm{z}$ ) were acquired in the Orbitrap analyzer at 50,000 resolution. The lock-mass option was used to obtain the most accurate mass measurements in MS mode. The polydimethylcyclosoloxane ion generated in the electrospray process from the ambient air (protonated $\left.\left(\mathrm{Si}_{(}\left(\mathrm{CH}_{3}\right)_{2} \mathrm{O}\right) 6, \mathrm{~m} / \mathrm{z} 445.120025\right)$ was used for internal recalibration in real time. All LC-MS files were analyzed using the MS label free differential analysis software SIEVE v2.2 (ThermoFisher). SIEVE was run on all the LC-MS full-scan chromatograms using the component extraction setting. The chromatograms were time-aligned, blank subtracting (solvent background) and referencing the sample acquired in the middle of the sequence. The framing parameters were set at $0.01 \mathrm{Da}$ for the $\mathrm{m} / \mathrm{z}$ window and 0.35 min for the retention time (RT) window; 500,000 was used as the intensity threshold. For compound identification, the frame $\mathrm{m} / \mathrm{z}$ values were used for batch searches on the ChemSpider database

VOCs have been extracted from the resins using the SPME (solid phase micro extraction) method as from ISO TC 147/SC 17943 with modifications to include selected analytes. Cured resins have been reduced in fine powder before the analysis with a dismembrator. About $1 \mathrm{~g}$ of sample has been put into $6 \mathrm{ml}$ of water and incubated at $60^{\circ} \mathrm{C}$ for 1 hour. VOCs have been concentrated in the headspace by using a SPME DVB/CAR/PDMS30/50 $\mu \mathrm{m}$ fiber (Supelco) for $30 \mathrm{~min}$. The analysis have been performed using a GC/MS Agilent 5975 MSD in SIM/SCAN mode. Analytes have been separated on a CP-624 CB $(60 \mathrm{~m} \times 0.32 \mathrm{~mm} \times 1.80 \mu \mathrm{m}$ film) column (Varian).

The column oven program started at $50^{\circ} \mathrm{C}$ for $3 \mathrm{~min}$, followed by ramping at $8^{\circ} \mathrm{C} \mathrm{min}^{-1}$ to $200^{\circ} \mathrm{C}$, hold for 5 min and ramp at $15^{\circ} \mathrm{C} \min ^{-1}$ to $260^{\circ} \mathrm{C}$, final hold for $5 \mathrm{~min}$. The GC injector and detector temperatures have been set to $250^{\circ} \mathrm{C}$ and $280^{\circ} \mathrm{C}$, respectively. All the peaks have been identified from their mass spectra by comparison with spectra in NIST 05 library after an individual control. Were available, retention times were confirmed with internal databases generated with original standards.

Quantitative analysis have been performed in the resins using a $0.01 \mu \mathrm{g} / \mu \mathrm{l}$ of $\mathrm{p}$-xylene solution as internal standard. For the migration test a field experiment has been set up by Metropolitana Milanese Spa at the Armi aqueduct station in Milan. A steel pipe of $30 \mathrm{~cm}$ internal diameter and $30 \mathrm{~m}$ length has been relined with the resin vinyl ester acrylate and then filled with the aqueduct water. After 24 hours a sample of pipe coating and water have been collected and analyzed for VOCs and BPA identification. Quantitative analysis have been performed in water samples by GC/MS following EN pr17943 guidelines.

In order to evaluate the safety of these materials, we combining the toxicity data, reported in the safety data

Table 1. QSAR end-points that have been evaluated with the correspondent model in this study.

\begin{tabular}{cc}
\hline End-point & QSAR model \\
\hline Carcinogenicity & Carcinogenicity model (CAESAR version 2.1.6) \\
Developmental toxicity & Toxicity developmental model (CAESAR version 2.1.4) \\
Mutagenicity & Mutagenicity model (CAESAR version 2.1.10) \\
Biodegradability & Ready biodegradability model (version 1.0.6-DEV) \\
BCF bioconcentration factor & BCF model (CAESAR version 2.1.11) \\
\hline
\end{tabular}


sheets of each product, with the toxicological information available from the main international agencies for environmental and human health protection (EPA, WHO, IARC, EFSA) and from scientific literature.

BPA has been extracted using the SPME technique with a polyacrylate-85 $\mu \mathrm{m}$ fiber (Supelco). Cured resins have been fragmented and $1 \mathrm{~g}$ of the sample has been put into a vial containing $6 \mathrm{ml}$ of water for LC/MS analysis (Carlo Erba). $500 \mathrm{ng}$ of deuterated BPA have been added to each sample and heated for 1 hour at $60^{\circ} \mathrm{C}$ using the heating plate Thermoblock (FALC Instruments). The fiber has been completely immersed for 30 minutes. The analysis have been performed by using a GC/MS Agilent 5973 MSD in SIM mode with the separation of analytes on a SLB- $5 \mathrm{~ms}(60 \mathrm{~m} \times 0.25 \mathrm{~mm} \times 0.25 \mu \mathrm{m}$ film) column (Supelco). The column oven program started at $100^{\circ} \mathrm{C}$ for $1 \mathrm{~min}$, followed by ramping at $10^{\circ} \mathrm{C} \mathrm{min}^{-1}$ to $300^{\circ} \mathrm{C}$, for $10 \mathrm{~min}$. The GC injector and detector temperatures have been set to $280^{\circ} \mathrm{C}$. For quantification a calibration curve has been prepared with $500 \mathrm{ng}$ of deuterated BPA and increasing concentrations of native BPA (0:500; 100:500; 500:500) in $6 \mathrm{ml}$ of water.

\section{Results}

\subsection{In Silico Models for Toxicological Properties}

The MSDS of some compounds were lacking of some important toxicological information such as mutagenicity, developmental toxicity, carcinogenicity. All the missing data have been derived from in silico methods, using QSAR models, and results are reported in Table 2. For each compound the end-points considered, prediction results and their reliability expressed by the $\mathrm{AD}$ index have been reported.

Table 2. The MSDS of some compounds were lacking of some important toxicological information such as mutagenicity, developmental toxicity, carcinogenicity. All the missing data have been derived from QSAR models application and results are reported in.

\begin{tabular}{|c|c|c|c|c|c|c|}
\hline & Samples & Cancerogenicity & Mutagenicity & $\begin{array}{l}\text { Developmental } \\
\text { toxicity }\end{array}$ & BCF (fish) & Biodegradability \\
\hline $\begin{array}{l}\text { Biacrylate glicol-tripolipropilene } \\
\text { CAS. 42978-66-5 }\end{array}$ & $\begin{array}{l}\text { Urethane } \\
\text { acrylate }\end{array}$ & $\begin{array}{l}\text { Carcinogen } \\
\qquad \begin{array}{c}\text { AD }=0 \\
\text { Not reliable }\end{array}\end{array}$ & $\begin{array}{l}\text { Non mutagenic } \\
\qquad \begin{array}{c}\text { AD }=0.99 \\
\text { Reliable }\end{array}\end{array}$ & $\begin{array}{c}\text { Not toxic } \\
\text { AD }=0.626 \\
\text { Not reliable }\end{array}$ & $\begin{array}{c}\text { Log BCF }=0.39 \\
\text { Ad }=0.572 \\
\text { Not reliable }\end{array}$ & $\begin{array}{l}\text { Biodegradable } \\
\begin{array}{c}\text { AD }=0.928 \\
\text { Reliable }\end{array}\end{array}$ \\
\hline $\begin{array}{l}\text { Propylenglycole diacrylate } \\
\text { CAS. 57472-68-1 }\end{array}$ & $\begin{array}{l}\text { Urethane } \\
\text { acrylate }\end{array}$ & $\begin{array}{l}\text { Carcinogen } \\
\qquad \begin{array}{c}\text { AD }=0 \\
\text { Not reliable }\end{array}\end{array}$ & $\begin{array}{l}\text { Non mutagenic } \\
\qquad \begin{array}{c}\text { AD }=0.99 \\
\text { Reliable }\end{array}\end{array}$ & $\begin{array}{l}\text { Not toxic } \\
\text { AD = } 0.63 \\
\text { Not reliable }\end{array}$ & $\begin{array}{c}\text { Log BCF }=0.52 \\
\text { AD }=0.59 \\
\text { Not reliable }\end{array}$ & $\begin{array}{l}\text { Biodegradable } \\
\begin{array}{c}\text { AD }=0.933 \\
\text { Reliable }\end{array}\end{array}$ \\
\hline $\begin{array}{c}\text { Ethoxylated trimethylolpropane } \\
\text { tryacrylate } \\
\text { CAS. 28961-43-5 }\end{array}$ & $\begin{array}{l}\text { Epoxy } \\
\text { acrylate }\end{array}$ & $\begin{array}{l}\text { Not carcinogen } \\
\qquad \begin{array}{l}\text { AD }=0.591 \\
\text { Not reliable }\end{array}\end{array}$ & $\begin{array}{l}\text { Non mutagenic } \\
\begin{array}{c}\text { AD }=0.939 \\
\text { Reliable }\end{array}\end{array}$ & $\begin{array}{l}\text { Not toxic } \\
\text { AD = 0.63 } \\
\text { Not reliable }\end{array}$ & $\begin{array}{c}\log B C F=-0.04 \\
\text { AD }=0.58 \\
\text { Not reliable }\end{array}$ & $\begin{array}{l}\text { Biodegradable } \\
\begin{array}{c}\text { AD }=0.921 \\
\text { Reliable }\end{array}\end{array}$ \\
\hline $\begin{array}{c}\text { Trimethylopropane triacrylate } \\
\text { CAS. 15625-89-5 }\end{array}$ & $\begin{array}{l}\text { Epoxy } \\
\text { acrylate }\end{array}$ & $\begin{array}{l}\text { Not carcinogen } \\
\qquad \begin{array}{c}\text { AD }=0 \\
\text { Not reliable }\end{array}\end{array}$ & $\begin{array}{l}\text { Mutagenic } \\
\text { AD = } 1 \\
\text { Reliable }\end{array}$ & $\begin{array}{c}\text { Not toxic } \\
\text { AD }=0 \\
\text { Not reliable }\end{array}$ & $\begin{array}{c}\text { Log BCF }=0.48 \\
\text { AD }=0.573 \\
\text { Not reliable }\end{array}$ & $\begin{array}{l}\text { Biodegradable } \\
\begin{array}{c}\text { AD }=0.923 \\
\text { Reliable }\end{array}\end{array}$ \\
\hline $\begin{array}{l}\text { 2-hydroxyethylmethacrylate } \\
\text { CAS. 868-77-8 }\end{array}$ & $\begin{array}{l}\text { Epoxy } \\
\text { acrylate }\end{array}$ & $\begin{array}{l}\text { Carcinogen } \\
\text { AD }=0.49 \\
\text { Not reliable }\end{array}$ & $\begin{array}{l}\text { Non mutagenic } \\
\qquad \begin{array}{c}\mathrm{AD}=1 \\
\text { Reliable }\end{array}\end{array}$ & $\begin{array}{c}\text { Toxic } \\
\text { AD }=0.671 \\
\text { Not reliable }\end{array}$ & $\begin{array}{c}\log \mathrm{BCF}=0.18 \\
\mathrm{AD}=0.586 \\
\text { Not reliable }\end{array}$ & $\begin{array}{l}\text { Biodegradable } \\
\qquad \begin{array}{c}\mathrm{AD}=1 \\
\text { Reliable }\end{array}\end{array}$ \\
\hline $\begin{array}{l}\text { Acrylic acid } \\
\text { CAS. } 79-10-7\end{array}$ & $\begin{array}{l}\text { Epoxy } \\
\text { acrylate }\end{array}$ & $\begin{array}{c}\mathrm{AD}=0 \\
\text { Not reliable }\end{array}$ & $\begin{array}{l}\mathrm{AD}=0.94 \\
\text { Reliable }\end{array}$ & $\begin{array}{c}\mathrm{AD}=0 \\
\text { Not reliable }\end{array}$ & $\begin{array}{c}\text { LogBCF }=0.1 \\
\text { Do not } \\
\text { Bioaccumulate } \\
\text { AD }=0.85 \\
\text { Reliable }\end{array}$ & $\begin{array}{l}\mathrm{AD}=1 \\
\text { Reliable }\end{array}$ \\
\hline $\begin{array}{l}\text { 2-hydroxyethylacrylate } \\
\text { CAS. 818-61-1 }\end{array}$ & $\begin{array}{l}\text { Epoxy } \\
\text { acrylate }\end{array}$ & $\begin{array}{c}\mathrm{AD}=0 \\
\text { Not reliable }\end{array}$ & Non mutagenic & $\begin{array}{l}\mathrm{AD}=0.654 \\
\text { Not reliable }\end{array}$ & $\begin{array}{l}\mathrm{AD}=0.615 \\
\text { Not reliable }\end{array}$ & $\begin{array}{l}\mathrm{AD}=1 \\
\text { Reliable }\end{array}$ \\
\hline
\end{tabular}


Results shown that the predictions are not reliable for carcinogenicity, developmental toxicity and bioconcentration factor (BCF). More reliable results have been therefore obtained for mutagenicity (Ames test) and biodegradability, with $\mathrm{AD}$ index values close to 1 .

In general, the compounds are not mutagenic except trimethylopropane triacrylate (urethane acrylate and epoxy acrylate based resins) that results to be mutagenic.

This is confirmed in the material safety data sheet of epoxy acrylate but only for in the vitro tests. For glycidyl phenol/formaldehyde polymer in epoxy novolac acrylate resin, it has not been possible to apply QSAR model for the complexity of the chemical structure. All compounds resulted biodegradable.

\subsection{HPLC/MS}

In Figure 1, an HPLC chromatogram of vinyl ester acrylate UV resin is shown. Chromatographic peaks, obtained with high resolution MS, have been analyzed and SIEVE identification are reported. All resins showed different profiles, up to 2500 features were detected in positive ionization mode, while the negative ionization mode did not present any features. The different chromatographic profiles of the resins obtained in positive ionization mode indicated that they are qualitatively different. Among the 2500 features ChemSpider has assigned for each one about 20 possible compounds with comparable $\mathrm{m} / \mathrm{z}$ value for this reason many of them have not identified. Among the identify features the most abundant chemicals acrylate compounds are normally present in these materials and have been identified. In Figure 2, an expanded view of mass spectra at 24.87 min retention time is reported along with tentative composition identification and relative error.

Here, identification of an acrylate has been possible with SIEVE software and ChemSpider database, as dipropylene glycol diacrylate (CAS. 57472-68-1) with an error of $-0.58 \mathrm{ppm}$ in mass assignement. The different profiles of the resins, as from the SIEVE output reported in Figure 3, indicated that they are qualitatively

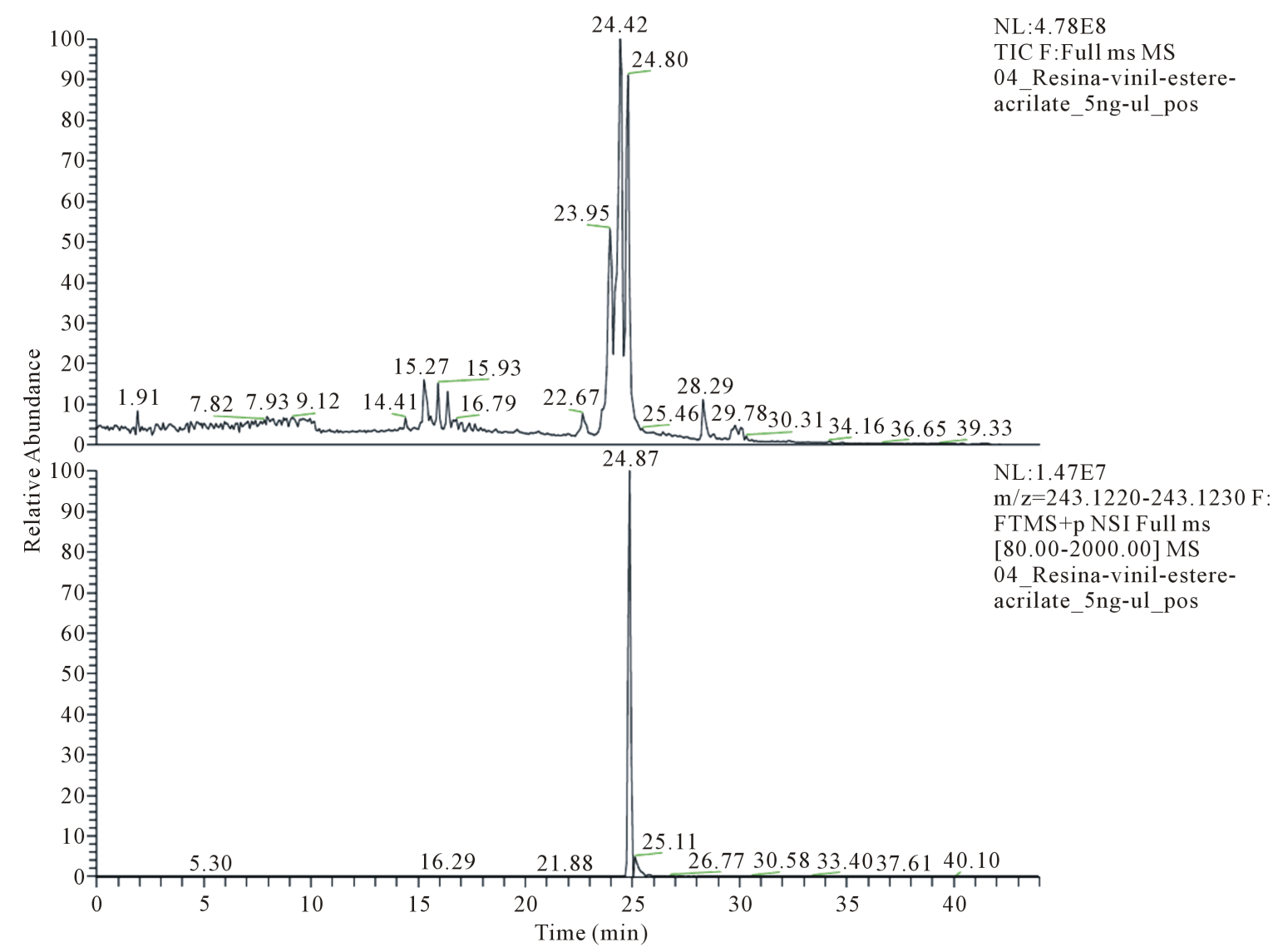

Figure 1. HPLC chromatogram of vinyl ester acrylate UV resin, upper box, and an extracted chromatogram of the base peak at $28.8 \mathrm{~min}$ retention time (lower box) indicating a single compound present at that mass. 
04 Resina-vinil-estere-acrilate_5ng-ul_pos\#1416 RT:24.80 AV:1 NL:1.09E7

$\mathrm{T}: \bar{F}$ TMS + p NSI Full ms [80.00-2000.00]

243.1226

$\mathrm{C}_{12} \mathrm{H}_{19} \mathrm{O}_{5}$

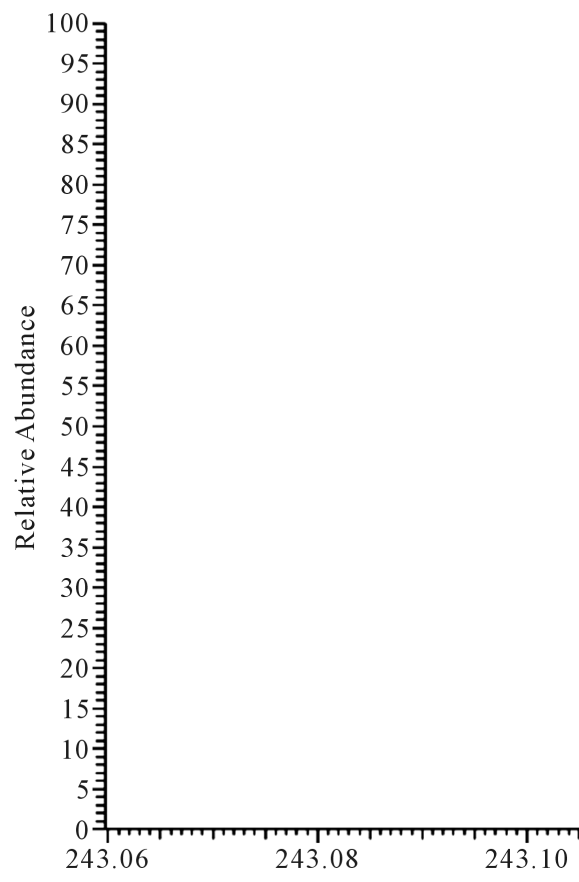

$-0.5823 \mathrm{ppm}$

243.06

243.10

243.12

243.14

243.16

243.18

$\mathrm{m} / \mathrm{z}$

Figure 2. Expanded view of high resolution mass spectrum of peak from Figure 1 at 24.87 min retention time. Formula assignment and relative error are plotted.

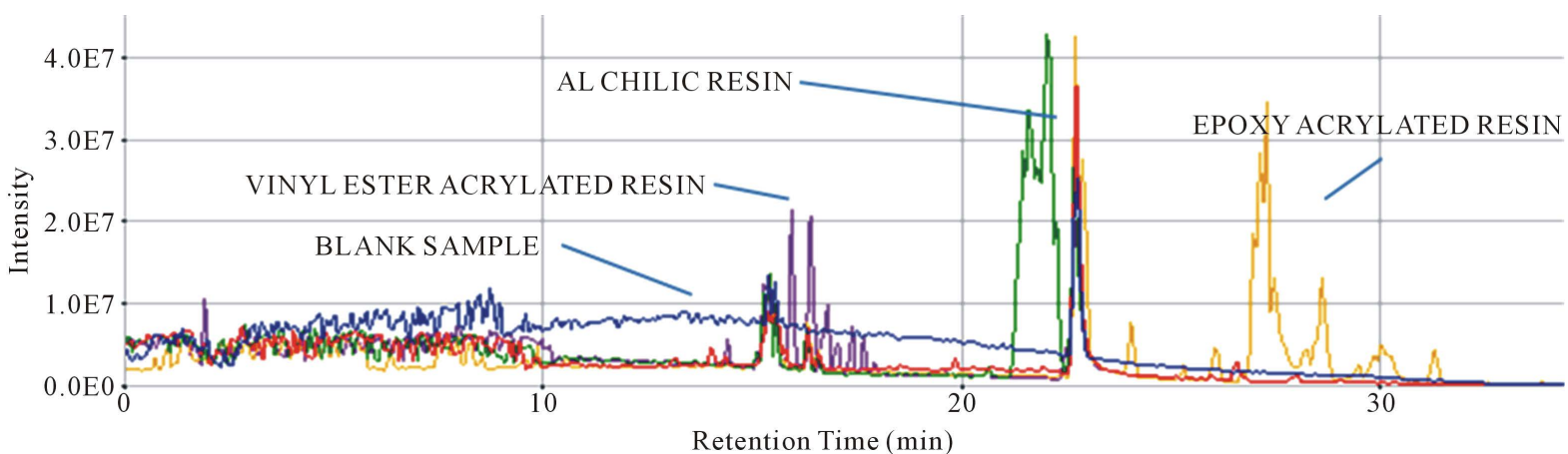

\begin{tabular}{|c|c|c|c|c|c|}
\hline \multicolumn{2}{|c|}{ MZ } & Time & MS2 & & GoodID \\
\hline 1 & 348.2025 & 24.423 & & 4 & \\
\hline 2 & 304.1757 & 24.799 & & 3 & 0 \\
\hline 3 & 436.2544 & 23.954 & & 4 & 0 \\
\hline 4 & 480.2791 & 23.875 & & 2 & 0 \\
\hline 5 & 392.2289 & 24.346 & & 0 & 0 \\
\hline 6 & 113.0591 & 24.799 & & 0 & 19 \\
\hline 7 & 113.0591 & 24.423 & & 0 & 19 \\
\hline 8 & 780.4014 & 28.63 & & 2 & 0 \\
\hline 9 & 334.1858 & 30.243 & & 1 & 0 \\
\hline 10 & 192.1383 & 22.617 & & 0 & 22 \\
\hline 11 & 287.149 & 24.799 & & 3 & 3 \\
\hline 12 & 349.2052 & 24.423 & & 0 & 0 \\
\hline 13 & 113.0594 & 24.186 & & 0 & 19 \\
\hline 14 & 502.2425 & 29.19 & & 5 & 0 \\
\hline 15 & 422.2384 & 29.686 & & 2 & 0 \\
\hline 16 & 378.2123 & 30.15 & & 3 & 0 \\
\hline 17 & 348.2018 & 24.115 & & 2 & 0 \\
\hline
\end{tabular}

\begin{tabular}{|c|c|c|c|c|c|c|c|}
\hline Name & Formula & SMILES & MolecularWeight & AverageMass & MonoisotopicMass & SearchMass & DeltaPPM \\
\hline DEET & $C_{-}\{12\} \mathrm{H}_{-}$ & $\mathrm{O}=\mathrm{C}(\mathrm{c} 1 \mathrm{cc})$ & 191.2695 & 191.2695 & 191.131012 & 191.131106 & 0.491589307 \\
\hline N-butyl acetylaniline & $C_{-}\{12\} \mathrm{H}_{-}$ & $0=C(N(c 1 c$ & 191.2695 & 191.2695 & 191.131012 & 191.131106 & 0.491589307 \\
\hline Butylacetanilide & $C_{-}\{12\} H_{-}$ & $0=C(N C 1 C C$ & 191.2695 & 191.2695 & 191.131012 & 191.131106 & 0.491589307 \\
\hline N,N-diethyl-2-phenyla; & $C_{-}\{12\} \mathrm{H}_{-}$ & $\operatorname{con}(\mathrm{CC}) \mathrm{Cl}$ & 191.2695 & 191.2695 & 191.131012 & 191.131106 & 0.491589307 \\
\hline Indanorex & $C_{-}\{12\} \mathrm{H}_{-}$ & $O C 2(\operatorname{Cc} 10 C$ & 191.2695 & 191.2695 & 191.131012 & 191.131106 & 0.491589307 \\
\hline 0-Tolualdehyde, 4- (d C & $C_{-}\{12\} \mathrm{H}_{-}$ & $0=\operatorname{cc} 1 c(c c)$ & 191.2695 & 191.2695 & 191.131012 & 191.131106 & 0.491589307 \\
\hline $\mathrm{N}$-(4-butylphenyl)acet: & $C_{-}\{12\} \mathrm{H}_{-}$ & $0=C(N C 1 C S$ & 191.2695 & 191.2695 & 191.131012 & 191.131106 & 0.491589307 \\
\hline 1-benzylpiperidin-4-ol & $C_{-}\{12\} H_{-}$ & $0 \mathrm{OC} 2 \mathrm{Can}(\mathrm{C}$ & 191.2695 & 191.2695 & 191.131012 & 191.131106 & 0.491589307 \\
\hline 4-benzylpiperidin-4-ol & $C_{-}\{12\} \mathrm{H}_{-}$ & $O C 2\left(\mathrm{CC}_{10 C}\right.$ & 191.2695 & 191.2695 & 191.131012 & 191.131106 & 0.491589307 \\
\hline p-tert-Butylacetanilide & $C_{-}\{12\} \mathrm{H}_{-}$ & $0=C(N C 1 C C$ & 191.2695 & 191.2695 & 191.131012 & 191.131106 & 0.491589307 \\
\hline 2-(Diethylamino)-1-ph & $C_{-}\{12\} H_{-}$ & $0=C(c 1 c c c$ & 191.2695 & 191.2695 & 191.131012 & 191.131106 & 0.491589307 \\
\hline (3S)-1-benzylpiperidir & $C_{-}\{12\} H_{-}$ & $\mathrm{O}[\mathrm{C} \odot \mathrm{H}] 2 \mathrm{C}$ & 191.2695 & 191.2695 & 191.131012 & 191.131106 & 0.491589307 \\
\hline$[(2 S)-1-$ Benzylpyrrolid & $C_{-}\{12\} \mathrm{H}_{-}$ & $\mathrm{OC}[\mathrm{C \odot H}] 2$ & 191.2695 & 191.2695 & 191.131012 & 191.131106 & 0.491589307 \\
\hline 2,6-Dimethylisobutyra & $C_{-}\{12\} \mathrm{H}_{-}$ & $0=C(N c 1 C s$ & 191.2695 & 191.2695 & 191.131012 & 191.131106 & 0.491589307 \\
\hline 1-(2-Pyridyl)-2-heptar & $C_{-}\{12\} H_{-}$ & $0=C(C c 1 n c$ & 191.2695 & 191.2695 & 191.131012 & 191.131106 & 0.491589307 \\
\hline 2-Methoxy-4-methyl-6 & $C_{-}\{12\} H_{-}$ & $O(c 1 n c 2 c(s)$ & 191.2695 & 191.2695 & 191.131012 & 191.131106 & 0.491589307 \\
\hline$(3 \mathrm{~S}, 4 \mathrm{~S})-4$-Benzyl-3-pi & $C_{-}\{12\} \mathrm{H}_{-}$ & $\mathrm{O}[\mathrm{C} \odot \mathrm{H}] 2[\mathrm{C}$ & 191.2695 & 191.27 & 191.1309967 & 191.131106 & 0.57161761 \\
\hline 4-(4-Methoxyphenyl)p & $C_{-}\{12\} \mathrm{H}_{-}$ & $O(\operatorname{clccc}(\mathrm{cc})$ & 191.2695 & 191.2695 & 191.131012 & 191.131106 & 0.491589307 \\
\hline 2. (nimothidaminol-2. & & 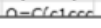 & 1012605 & 1012605. & 101.21012 & 101.121106 & م.015e0207 \\
\hline
\end{tabular}

Figure 3. SIEVE chromatograms alignment of high resolution MS data and tentative compounds identification. 
different. The software has identified more than 2500 values of $\mathrm{m} / \mathrm{z}$ and ChemSpider has assigned for each one about 20 possible compounds for this reason many compounds have not identified (red arrow). The most abundant chemicals are the acrylate compounds that are normally present in these materials.

\subsection{GC/MS}

VOCs have been analyzed in resins and their mixtures, before and after the curing process, and in water using the newly ISO Standard method 17,943, that should become available soon (in its Approval Stage, the international harmonized stage codes is 50.20: proof sent to secretariat, as from November 2015). This method shows high sensitivity and specificity for a large number of volatiles. The main advantage for this application is that SPME sampling can be used on virtually all kinds of matrices including, as in this case, resins. In Figure 4, a chromatogram from polyester + hydroxyethyl metacrylate (30\%) + urethane acrylate brand B (70\%) + 0.5\% photoinitiator sample is shown with an uncured resin where the complexity of samples can be appreciated.

The peak at a retention time of $19.3 \mathrm{~min}$ is BPA, in Figure 5 an expanded view of the chromatogram, showing that chromatogaphy is good, and analytes of interests are clearly resolved from other volatile compounds.

In Tables 3(a)-(e), the results of VOCs analysis performed by GC/MS are reported for all resins. In this study, only the most toxic and abundant compounds have been considered. For the VOCs unidentified by the instrumental library (NIST) the retention time (RT) or their chemical category (e.g. hydrocarbon, alcohol, esters, aldehydes, ketones, terpenes) are reported.

The uncured resins have higher variety and concentrations of VOCs than the cured resins. Chromatogram from uncured and polymerized sample of epoxy acrylate brand B is sown in Figure 6(a) and Figure 6(b). This may confirm the fact that during the mixing or curing process some of these compounds can both evaporate [4] or remain trapped in the resins. Limit of quantification (LOQ) has been reported for undetected compounds. This resin has been used for the migration filed test (Figure 7).

\section{Discussions}

The vinyl ester acrylate resin contains higher levels of chlorinated hydrocarbons than the others. Generally aliphatic and aromatic hydrocarbons are impurities contained in the solvent. Toluene has been found in almost samples analyzed. Toluene as well as xylenes are aromatic hydrocarbons commonly used as industrial solvent for the manufacturing of paints, resins and coating [5].

Styrene has been found in the vinyl ester acrylate and polyester resins. This chemical is the most common monomers used in cross linking agents in polymerization process [6] [7]. Vinyl ester resins usually contain styrene, used to reduce the resin viscosity and improves overall polymer properties by allowing for a higher degree of reaction of the monomers [8]. Esters and acrylate compounds are also present in resins.

BHA (Butylated Hydroxyanisole) and BHT (Butylated Hydroxytoluene) are used as stabilizer in polymer industry [9] and are commonly found.

The toxicity of these compounds is highly variable, range from chemicals considered probable or possible human carcinogens (eg, styrene, methyl isobutyl ketone, BHA) to others with limited toxicological information (eg. propenoic acid esters). The exposure to these compounds is regulated by the principal agencies responsible for the human health protection (EPA, EFSA, WHO).

RfD (EPA) and ADI (EFSA) values have been used to calculate the daily dose of the chemicals measured that can be assumed from an adult (60 kg body weight) during lifetime without appreciable risk for health (Table 4).

VOCs results showed concentrations ranging from $0.01 \mu \mathrm{g} / \mathrm{g}$ to $94 \mu \mathrm{g} / \mathrm{g}$ in the resins before polymerization and less than the LOD $(<0.01 \mu \mathrm{g} / \mathrm{g})$ after polymerization. The migration field test, the experimental setup is shown in Figure 8, resulted in negligible solvents water concentrations.

Butylene glycol dimethacrylate, has been found in water with a concentration of $0.12 \mathrm{ng} / \mu \mathrm{l}$. According to QSAR models is not carcinogenic or mutagenic compound, but biodegradable and skin sensitizer.

BPA concentrations in resins are reported in Table 5. It has been found in all resins beside in epoxy acrylate brand $\mathrm{B}$ and urethane acrylate brand $\mathrm{B}$, but in the migration field test, in water, it was below detection limits ( $<2$ $\mathrm{mg} / \mathrm{L}$ by GC/MS).

In Table 6, the results of the VOCs analysis in the migration field test are reported. Results indicated that the release of VOCs from the resin into the water appears to be negligible. 
Abundance

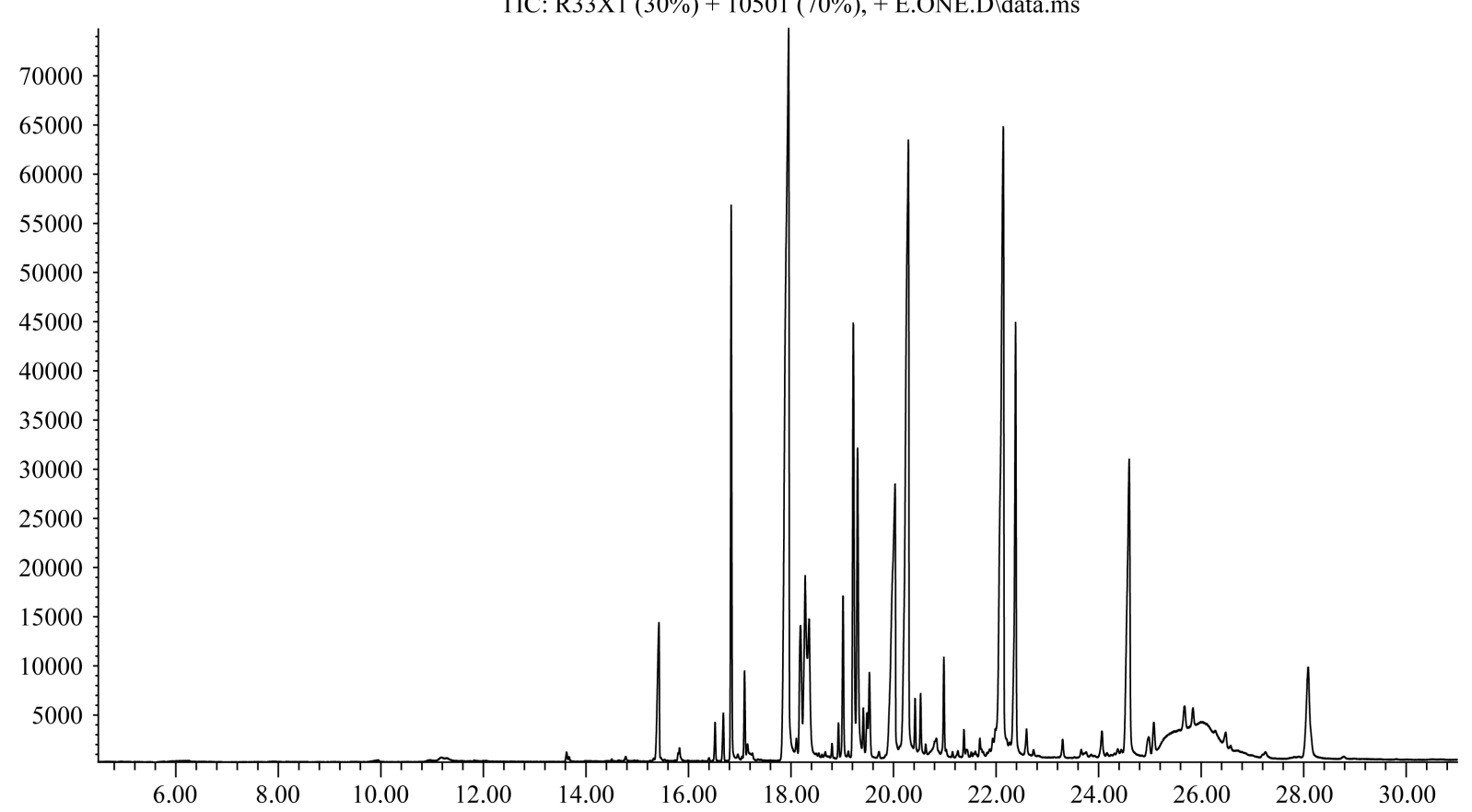

Time-->

Figure 4. Full scan GC/MS chromatogram of a resin, directly sampled with SPME fiber. The sampling approach allows direct analysis of complex and difficult matrices, like a resin. Several volatiles are present and chromatography is not disturbed.

Abundance

Ion 228.00 (227.70 to 228.70): R33X1 (30\%) + 10501 (70\%), + E.ONE.D \data.ms

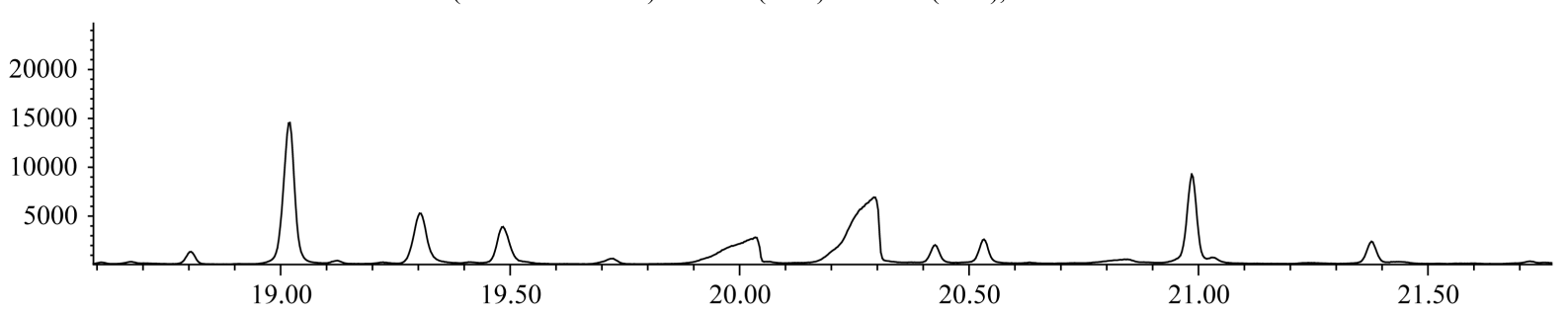

Time-->

Abundance

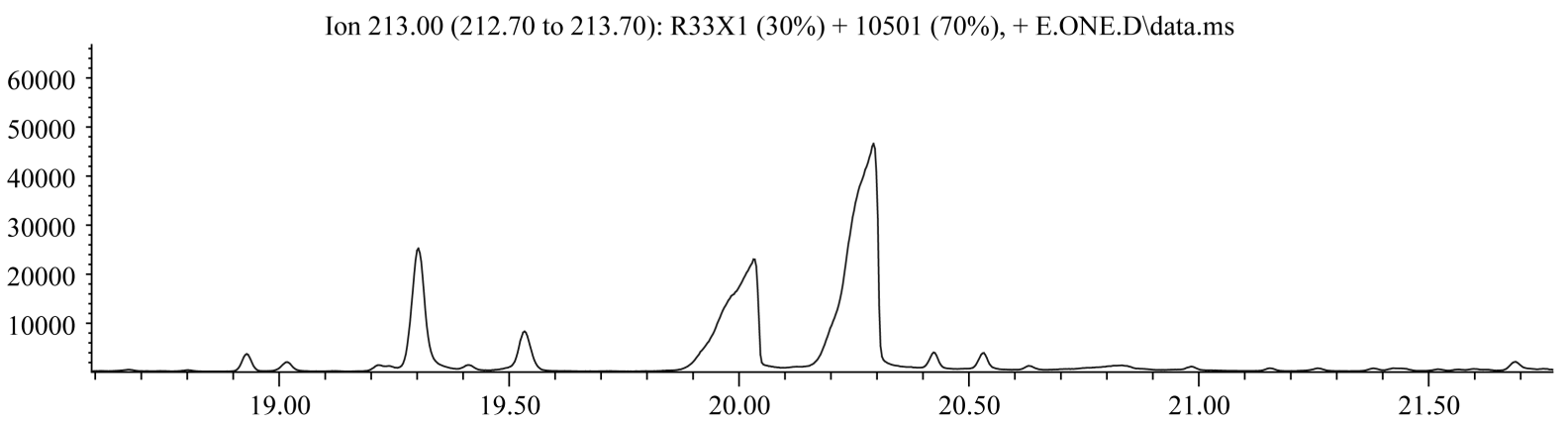

Time-->

Figure 5. Expanded view of chromatogram in Figure 1. The peak at retention time of 19.3 min if bisphenol A, as verified with an original standard (data not shown). 
Abundance

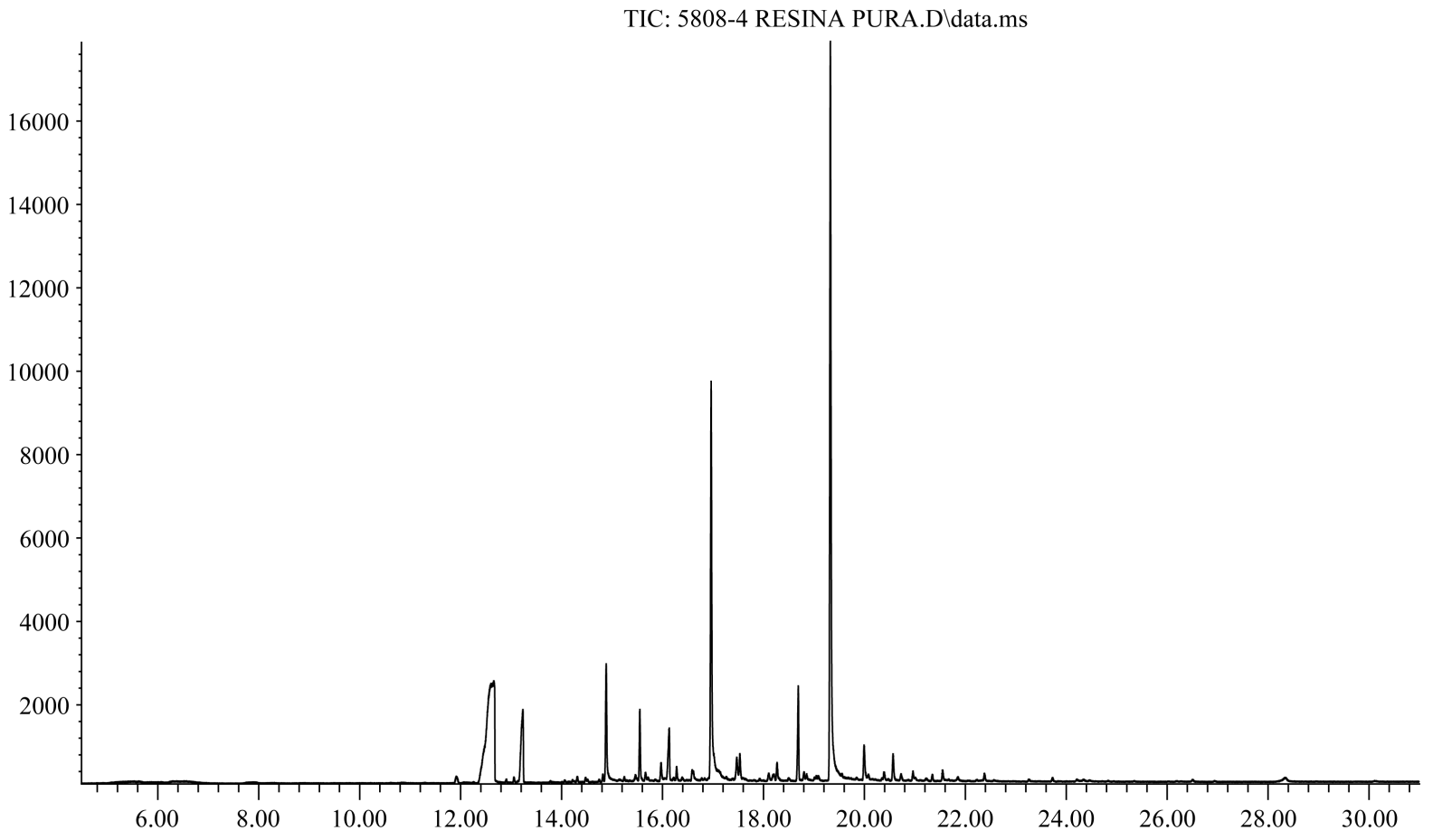
Time-->

(a)

Abundance

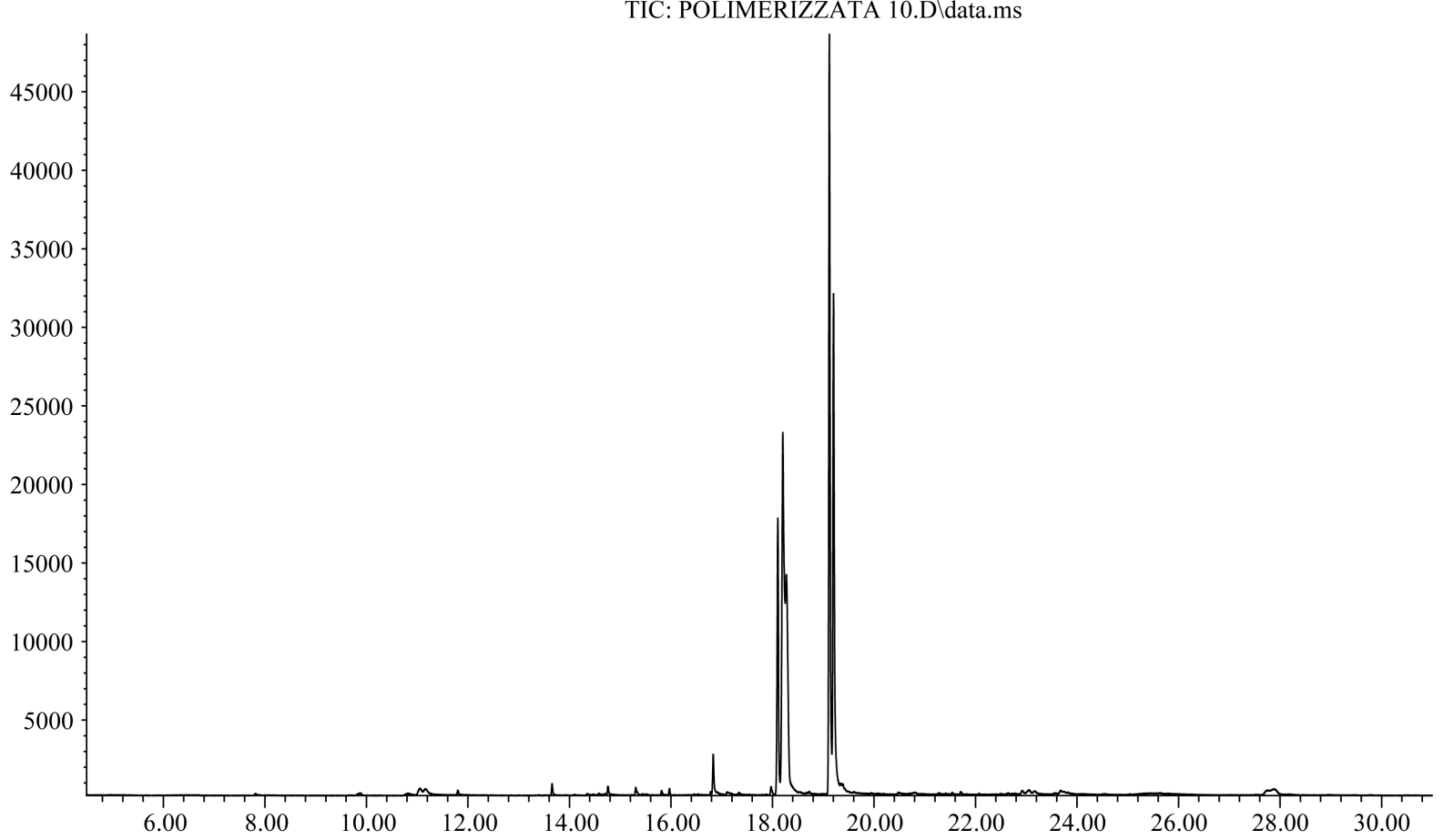

Time-->

(b)

Figure 6. (a) (upper) and (b) (lower). Full scan GC/MS chromatograms of epoxy acrylate brand B resin. The polymerization process reduces free volatile compounds. 


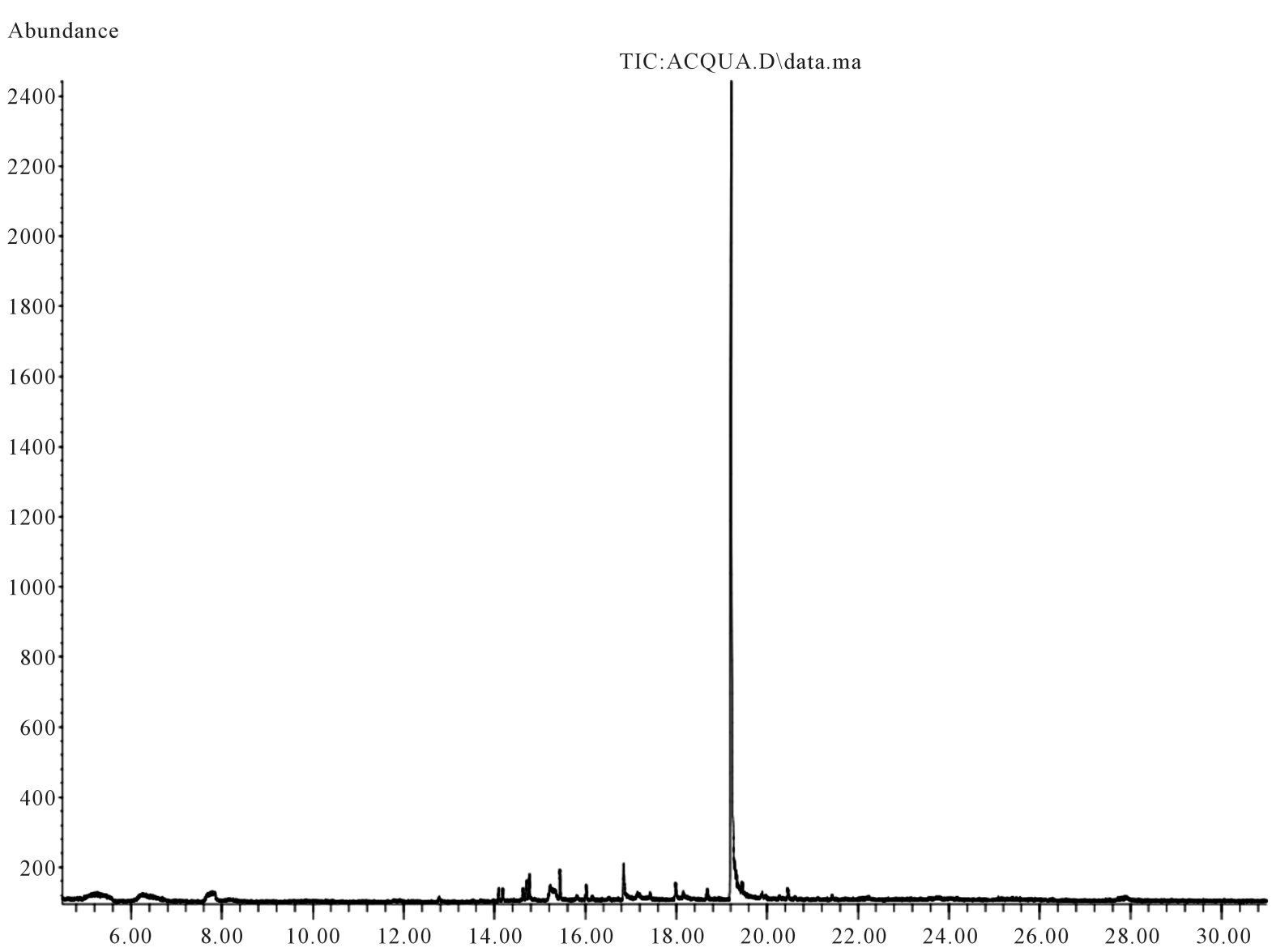

Time-->

Figure 7. Full scan GC/MS chromatograms of water sample after migration field test. The pipe was relined with epoxy acrylate brand B resin.
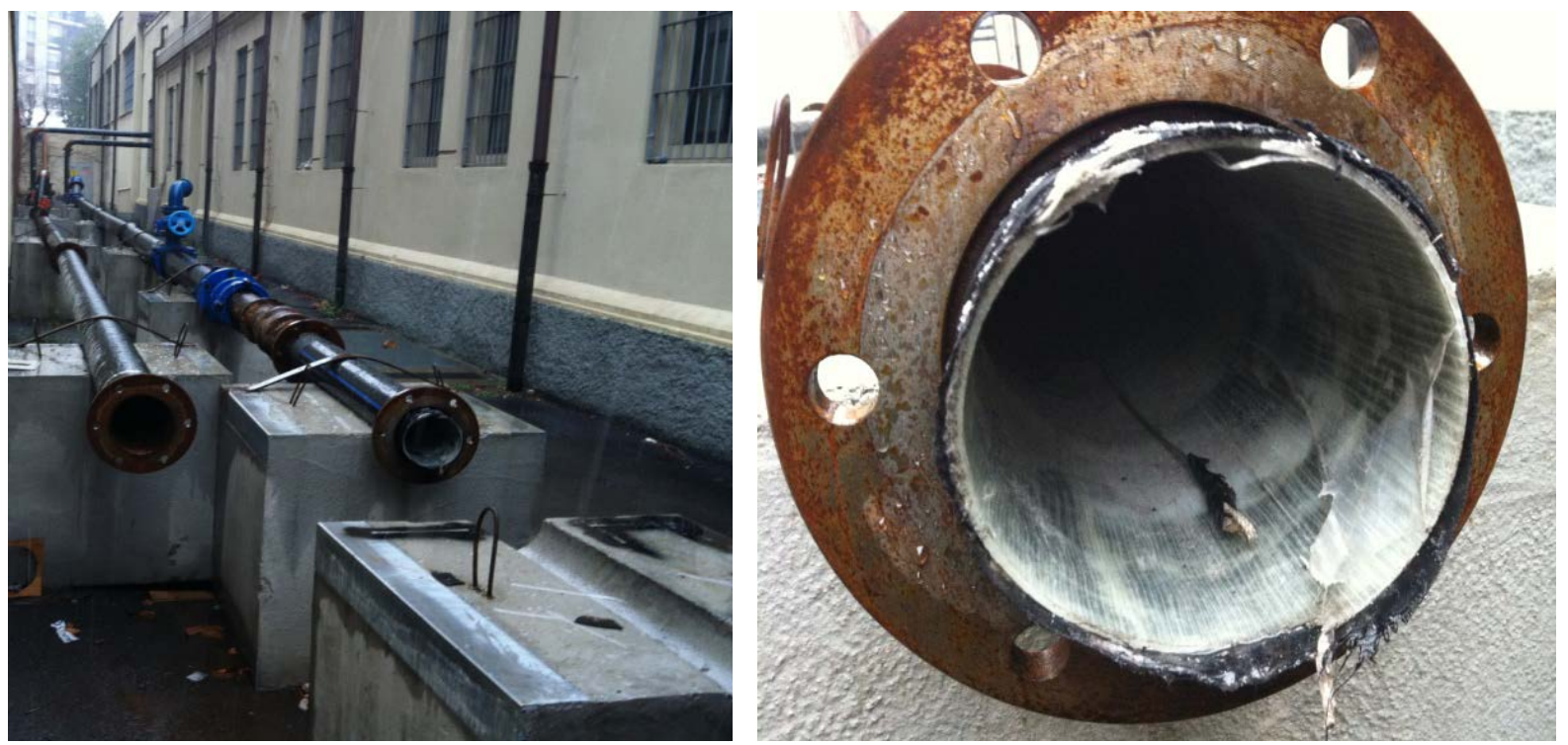

Figure 8. Field test at the Armi station in Milano and a close-up of the pipe relined. A $30 \mathrm{~m}, 30 \mathrm{~cm}$ ID steel pipe $30 \mathrm{~m}$ has been relined with the vinyl ester acrylate resin, filled with aqueduct water and, after $24 \mathrm{~h}$ the water has been sampled and analysed as described in the text. 
Table 3. (a) VOCs analysis results expressed as $\mu \mathrm{g} / \mathrm{g}$ of resin. Cured resins are underlined; (b) VOCs analysis results expressed as $\mu \mathrm{g} / \mathrm{g}$ of resin. Cured resins are underlined; (c) VOCs analysis results expressed as $\mu \mathrm{g} / \mathrm{g}$ of resin. Cured resins are underlined; (d) VOCs analysis results expressed as $\mu \mathrm{g} / \mathrm{g}$ of resin. Cured resins are underlined; (e) VOCs analysis results expressed as $\mu \mathrm{g} / \mathrm{g}$ of resin. Cured resins are underlined.

\section{(a)}

\begin{tabular}{|c|c|c|c|c|c|c|c|c|c|c|}
\hline \multirow[b]{2}{*}{ Resins } & \multicolumn{10}{|c|}{ Identified compounds } \\
\hline & $\begin{array}{l}\text { Propenoic } \\
\text { acid ester } \\
\text { (RT 11.73) }\end{array}$ & $\begin{array}{l}\text { Methyl } \\
\text { isobutyl } \\
\text { ketone }\end{array}$ & toluene & $\begin{array}{l}\text { Propenoic } \\
\text { acid ester } \\
\text { (RT 13.68) }\end{array}$ & $\begin{array}{l}\text { 4-methyl- } \\
\text { 3-penten- } \\
\text { 2-one }\end{array}$ & $\begin{array}{l}\text { Propenoic } \\
\text { acid ester } \\
\text { (RT 14.57) }\end{array}$ & $\begin{array}{l}\text { Dimethyl } \\
\text { dioxane }\end{array}$ & p-xylene & Styrene & RT (17.48) \\
\hline Epoxyacrylate brand B & $<0.06$ & 0.30 & 1.27 & $<0.06$ & 0.07 & $<0.06$ & 0.02 & 0.24 & $<0.06$ & $<0.06$ \\
\hline $\begin{array}{c}\text { Epoxyacrylate brand B (50\%) } \\
\text { + urethane acrylate brand } \\
\text { B (50\%) }\end{array}$ & $<0.01$ & 0.12 & 1.21 & $<0.01$ & 0.03 & $<0.01$ & 0.02 & 0.11 & $<0.01$ & $<0.01$ \\
\hline $\begin{array}{l}\text { Epoxyacrylate brand B (50\%) } \\
\text { + urethane acrylate brand } \\
\text { B (50\%) }\end{array}$ & $<0.03$ & 0.03 & 0.37 & $<0.03$ & 0.01 & $<0.03$ & $<0.03$ & 0.08 & $<0.03$ & $<0.03$ \\
\hline Hydroxyethyl metacrylate & 2.42 & $<0.02$ & 0.09 & $<0.02$ & 1.43 & $<0.02$ & $<0.02$ & $<0.02$ & $<0.02$ & $<0.02$ \\
\hline $\begin{array}{l}\text { Polyester (+hydroxyethyl } \\
\text { methacrylate } 30 \%)(30 \%) \\
\text { + urethane acrylate brand } \\
\text { B (70\%) }\end{array}$ & 0.21 & $<0.2$ & 1.21 & $<0.2$ & 0.17 & $<0.2$ & $<0.2$ & $<0.2$ & 21.67 & $<0.2$ \\
\hline $\begin{array}{l}\text { Polyester (+hydroxyethyl } \\
\text { methacrylate } 30 \%)(30 \%) \\
\text { + urethane acrylate brand } \\
\text { B }(70 \%)+15 \text { sec }^{\mathrm{a}}\end{array}$ & $<0.02$ & $<0.02$ & 0.22 & $<0.02$ & $<0.02$ & $<0.02$ & $<0.02$ & 0.11 & $<0.02$ & $<0.02$ \\
\hline $\begin{array}{l}\text { Polyester (+hydroxyethyl } \\
\text { methacrylate } 30 \%)(30 \%) \\
\text { + urethane acrylate brand } \\
\text { B }(70 \%),+30 \mathrm{sec}\end{array}$ & $<0.02$ & $<0.02$ & 0.15 & $<0.02$ & $<0.02$ & $<0.02$ & $<0.02$ & 0.09 & $<0.02$ & $<0.02$ \\
\hline Urethane acrylate brand B & $<0.03$ & $<0.03$ & 0.03 & $<0.03$ & $<0.03$ & $<0.03$ & 0.02 & 0.08 & $<0.03$ & $<0.03$ \\
\hline epoxy acrylate & $<0.02$ & 0.01 & 0.10 & $<0.02$ & $<0.02$ & $<0.02$ & $<0.02$ & 0.09 & $<0.02$ & $<0.02$ \\
\hline $\begin{array}{l}\text { Epoxy acrylate }+ \text { urethane } \\
\text { acrylate brand B } \\
\text { + photoinitiator }\end{array}$ & $<0.01$ & $<0.01$ & 0.32 & $<0.01$ & $<0.01$ & $<0.01$ & $<0.01$ & 0.09 & $<0.01$ & $<0.01$ \\
\hline $\begin{array}{l}\text { Epoxy acrylate + urethane } \\
\text { acrylate brand B }\end{array}$ & $<0.02$ & $<0.02$ & 0.07 & $<0.02$ & $<0.02$ & $<0.02$ & $<0.02$ & 0.07 & $<0.02$ & $<0.02$ \\
\hline Urethane acrylate brand A & $<0.02$ & $<0.02$ & 0.06 & $<0.02$ & $<0.02$ & $<0.02$ & $<0.02$ & 0.07 & $<0.02$ & 1.07 \\
\hline Urethane acrylate brand A UV & $<0.02$ & $<0.02$ & 2.19 & $<0.02$ & $<0.02$ & $<0.02$ & $<0.02$ & 0.08 & $<0.02$ & 1.37 \\
\hline $\begin{array}{l}\text { Urethane acrylate brand A } \\
\text { UV }+0.4 \% \text { photoinitiator }\end{array}$ & $<0.02$ & $<0.02$ & 0.20 & $<0.02$ & $<0.02$ & $<0.02$ & $<0.02$ & 0.08 & $<0.02$ & 0.01 \\
\hline photoinitiator & $<0.02$ & $<0.02$ & 3.01 & $<0.02$ & $<0.02$ & $<0.02$ & $<0.02$ & 0.09 & $<0.02$ & $<0.02$ \\
\hline $\begin{array}{l}\text { Polyester (50\%) + urethane } \\
\text { acrylate brand B (50\%) }\end{array}$ & $<0.06$ & $<0.06$ & $<0.06$ & $<0.06$ & $<0.06$ & $<0.06$ & $<0.06$ & $<0.06$ & 23.02 & $<0.06$ \\
\hline $\begin{array}{l}\text { Polyester }(50 \%)+\text { urethane } \\
\text { acrylate brand B (50\%) } \\
\text { + } 0.4 \% \text { photoinitiator }\end{array}$ & $<0.06$ & $<0.06$ & 0.45 & $<0.06$ & $<0.06$ & $<0.06$ & $<0.06$ & $<0.06$ & 10.04 & $<0.06$ \\
\hline $\begin{array}{l}\text { Polyester (50\%) + urethane } \\
\text { acrylate brand B (50\%) }\end{array}$ & $<0.03$ & $<0.03$ & 0.43 & $<0.03$ & $<0.03$ & $<0.03$ & $<0.03$ & $<0.03$ & $<0.03$ & $<0.03$ \\
\hline Vinyl ester acrylate & 0.37 & 0.03 & 0.10 & 0.24 & $<0.03$ & 0.19 & $<0.03$ & $<0.03$ & 5.12 & $<0.03$ \\
\hline Vinyl ester acrylate UV & $<0.03$ & 0.06 & 0.28 & 0.38 & $<0.03$ & 0.04 & $<0.03$ & $<0.03$ & $<0.03$ & $<\mathbf{0 . 0 3}$ \\
\hline $\begin{array}{l}\text { Vinyl ester acrylate UV } \\
\text { + photoinitiator }\end{array}$ & $<0.01$ & 0.01 & 0.07 & $<0.01$ & $<0.01$ & $<0.01$ & $<0.01$ & 0.10 & $<0.01$ & $<0.01$ \\
\hline
\end{tabular}

${ }^{\mathrm{a}}$ Time of UV curing. 


\section{(b)}

\begin{tabular}{|c|c|c|c|c|c|c|c|c|c|c|}
\hline \multirow[b]{2}{*}{ Resins } & \multicolumn{10}{|c|}{ Identified compounds cont. } \\
\hline & $\begin{array}{l}\text { 2,2,7,7- } \\
\text { tetramethyl } \\
\text { octane }\end{array}$ & $\begin{array}{l}\text { Heptane, } \\
\text { 2,2,4,6,6 } \\
\text {-penta } \\
\text { methyl }\end{array}$ & $\begin{array}{l}\text { Hydrocarbon } \\
\text { (RT 18.5) }\end{array}$ & $\begin{array}{l}\text { Heptane, } \\
\text { 2,2,4,6,6 } \\
\text { pentamethyl }\end{array}$ & $\begin{array}{l}\text { Decane, } \\
2,3,8 \\
\text { trimethyl }\end{array}$ & $\begin{array}{l}\text { Nonane, } \\
\text { 3,7- } \\
\text { dimethyl }\end{array}$ & $\begin{array}{l}\text { Nexane, } \\
\text { 1-(hexylox) } \\
\text {-5-methyl }\end{array}$ & $\begin{array}{l}\text { Trimethyl } \\
\text { benzene }\end{array}$ & Benzaldehyde & $\begin{array}{l}\text { Benzyl } \\
\text { chloride }\end{array}$ \\
\hline Epoxyacrylatebrand B & $<0.06$ & $<0.06$ & $<0.06$ & $<0.06$ & $<0.06$ & $<0.06$ & $<0.06$ & 0.03 & 0.24 & $<0.06$ \\
\hline $\begin{array}{c}\text { Epoxyacrylatebrand B } \\
\text { (50\%) + urethane acrylate } \\
\text { brand B }(50 \%)\end{array}$ & $<0.01$ & $<0.01$ & $<0.01$ & $<0.01$ & $<0.01$ & $<0.01$ & $<0.01$ & 0.01 & 0.13 & $<0.01$ \\
\hline $\begin{array}{c}\text { Epoxyacrylate brand B } \\
(50 \%)+\text { urethane acrylate } \\
\text { brand B ( } 50 \%)\end{array}$ & $<0.03$ & $<0.03$ & $<0.03$ & $<0.03$ & $<0.03$ & $<0.03$ & $<\mathbf{0 . 0 3}$ & $<0.03$ & $<0.03$ & 0.08 \\
\hline Hydroxyethyl metacrylate & $<0.02$ & $<0.02$ & $<0.02$ & $<0.02$ & $<0.02$ & $<0.02$ & $<0.02$ & 2.73 & 0.08 & $<0.02$ \\
\hline $\begin{array}{l}\text { Polyester (+hydroxyethyl } \\
\text { methacrylate } 30 \% \text { ) + urethane } \\
\text { acrylate brand B ( } 70 \%)\end{array}$ & $<0.2$ & $<0.2$ & $<0.2$ & $<0.2$ & $<0.2$ & $<0.2$ & $<0.2$ & 0.04 & $<0.2$ & $<0.2$ \\
\hline $\begin{array}{c}\text { Polyester (+hydroxyethyl } \\
\text { methacrylate } 30 \%)(30 \%) \\
\text { + urethane acrylate brand } \\
\text { B }(70 \%)+15 \text { sec }^{\mathrm{a}}\end{array}$ & $<0.02$ & $<0.02$ & $<0.02$ & $<0.02$ & $<0.02$ & $<0.02$ & $<0.02$ & $<0.02$ & $<0.02$ & $<0.02$ \\
\hline $\begin{array}{c}\text { Polyester (+hydroxyethyl } \\
\text { methacrylate } 30 \%)(30 \%) \\
\text { + urethane acrylate brand } \\
\text { B }(70 \%)+30 \text { sec }\end{array}$ & $<0.02$ & $<0.02$ & $<0.02$ & $<0.02$ & $<0.02$ & $<0.02$ & $<0.02$ & $<0.02$ & $<0.02$ & $<0.02$ \\
\hline Urethane acrylate brand B & $<0.03$ & $<0.03$ & $<0.03$ & $<0.03$ & $<0.03$ & $<0.03$ & $<0.03$ & $<0.03$ & $<0.03$ & $<0.03$ \\
\hline Epoxy acrylate & $<0.02$ & $<0.02$ & $<0.02$ & $<0.02$ & $<0.02$ & $<0.02$ & $<0.02$ & $<0.02$ & $<0.02$ & $<0.02$ \\
\hline $\begin{array}{l}\text { Epoxy acrylate }+ \text { urethane } \\
\text { acrylate brand B } \\
\text { + photoinitiator }\end{array}$ & $<0.01$ & $<0.01$ & $<0.01$ & $<0.01$ & $<0.01$ & $<0.01$ & $<0.01$ & $<0.01$ & $<0.01$ & $<0.01$ \\
\hline $\begin{array}{l}\text { Epoxy acrylate+urethane } \\
\text { acrylate brand B }\end{array}$ & $<0.02$ & $<0.02$ & $<0.02$ & $<0.02$ & $<0.02$ & $<0.02$ & $<0.02$ & $<0.02$ & $<0.02$ & $<0.02$ \\
\hline Urethane acrylate brand A & $<0.02$ & $<0.02$ & $<0.02$ & $<0.02$ & $<0.02$ & $<0.02$ & $<0.02$ & $<0.02$ & 0.01 & $<0.02$ \\
\hline Urethane acrylate brand A UV & $<0.02$ & $<0.02$ & $<0.02$ & $<0.02$ & $<0.02$ & $<0.02$ & $<0.02$ & $<0.02$ & $<0.02$ & $<0.02$ \\
\hline $\begin{array}{l}\text { Urethane acrylate brand A } \\
\text { UV }+0.4 \% \text { photoinitiator }\end{array}$ & $<0.02$ & $<0.02$ & $<0.02$ & $<0.02$ & $<0.02$ & $<0.02$ & $<0.02$ & $<0.02$ & $<0.02$ & $<0.02$ \\
\hline Photoinitiator & $<0.02$ & $<0.02$ & $<0.02$ & $<0.02$ & $<0.02$ & $<0.02$ & $<0.02$ & $<0.02$ & 0.01 & $<0.02$ \\
\hline $\begin{array}{l}\text { Polyester }(50 \%)+\text { urethane } \\
\text { acrylate brand B (50\%) }\end{array}$ & $<0.06$ & $<0.06$ & $<0.06$ & $<0.06$ & $<0.06$ & $<0.06$ & $<0.06$ & 0.17 & $<0.06$ & $<0.06$ \\
\hline $\begin{array}{l}\text { Polyester }(50 \%)+\text { urethane } \\
\text { acrylate brand B }(50 \%) \\
+0.4 \% \text { photoinitiator }\end{array}$ & $<0.06$ & $<0.06$ & $<0.06$ & $<0.06$ & $<0.06$ & $<0.06$ & $<0.06$ & 0.07 & $<0.06$ & $<0.06$ \\
\hline $\begin{array}{l}\text { Polyester (50\%) + urethane } \\
\text { acrylate brand B (50\%) }\end{array}$ & $<0.03$ & $<0.03$ & $<0.03$ & $<0.03$ & $<0.03$ & $<0.03$ & $<0.03$ & 0.02 & 0.01 & $<0.03$ \\
\hline Vinyl ester acrylate & 3.12 & 6.32 & 4.98 & 4.25 & 4.66 & 0.72 & 5.10 & $<0.03$ & $<0.03$ & $<0.03$ \\
\hline Vinyl ester acrylate UV & 3.59 & 4.06 & $<0.03$ & 4.98 & 4.83 & 1.22 & 4.59 & $<0.03$ & $<0.03$ & $<0.03$ \\
\hline $\begin{array}{l}\text { Vinyl ester acrylate UV } \\
+ \text { photoinitiator }\end{array}$ & 0.08 & 0.04 & $<0.01$ & 0.06 & 0.04 & 0.01 & 0.04 & $<0.01$ & $<0.01$ & $<0.01$ \\
\hline
\end{tabular}




\begin{tabular}{|c|c|c|c|c|c|c|c|c|c|c|}
\hline \multirow[b]{2}{*}{ Resins } & \multicolumn{10}{|c|}{ Identified compounds cont. } \\
\hline & $\begin{array}{l}\text { Trimethyl } \\
\text { decane } \\
\text { (RT 20.17) }\end{array}$ & $\begin{array}{c}\text { Alcohol } \\
\text { (RT 20.59) }\end{array}$ & $\begin{array}{l}\text { Propenoic } \\
\text { acid ester } \\
\text { (RT 20.69) }\end{array}$ & Phenol & $\begin{array}{c}\text { Ester } \\
\text { (RT 20.65) }\end{array}$ & $\begin{array}{c}\text { Ester } \\
\text { (RT 21.18) }\end{array}$ & $\begin{array}{c}\text { Ester } \\
(21.30)\end{array}$ & $\begin{array}{l}\text { Dimethyl } \\
\text { 1-Penten } \\
\text { 3-one }\end{array}$ & $\begin{array}{c}\mathrm{RT} \\
(23.22)\end{array}$ & $\begin{array}{l}\text { Propenoic } \\
\text { acid ester } \\
\text { (RT 23.86) }\end{array}$ \\
\hline $\begin{array}{l}\text { Epoxyacrylate brand B (50\%) } \\
\text { + urethane acrylate brand } \\
\text { B (50\%) }\end{array}$ & $<0.01$ & 12.35 & $<0.01$ & $<0.02$ & $<0.01$ & $<0.01$ & 0.25 & $<0.01$ & $<0.01$ & $<0.01$ \\
\hline $\begin{array}{c}\text { Epoxyacrylate brand B } \\
\text { (50\%) + urethane acrylate } \\
\text { brand B (50\%) }\end{array}$ & $<0.03$ & $<0.03$ & $<0.03$ & 0.05 & $<0.03$ & $<0.03$ & $<0.03$ & $<0.03$ & $<0.03$ & $<0.03$ \\
\hline $\begin{array}{c}\text { Polyester (+ hydroxyethyl } \\
\text { methacrylate } 30 \%)(30 \%) \\
\text { + urethane acrylate brand } \\
\text { B (70\%) }\end{array}$ & $<0.2$ & 74.70 & $<0.2$ & $<0.2$ & $<0.2$ & $<0.2$ & $<0.2$ & 4.60 & $<0.2$ & 0.97 \\
\hline $\begin{array}{c}\text { Polyester (+ hydroxyethyl } \\
\text { methacrylate } 30 \%)(30 \%) \\
\text { + urethane acrylate brand } \\
\text { B (70\%) + } 15 \text { sec }^{\mathrm{a}}\end{array}$ & $<0.02$ & $<0.02$ & $<0.02$ & $<0.02$ & $<0.02$ & $<0.02$ & $<0.02$ & $<0.02$ & $<0.02$ & $<0.02$ \\
\hline $\begin{array}{l}\text { Polyester (+ hydroxyethyl } \\
\text { methacrylate } 30 \%)(30 \%) \\
\text { + urethane acrylate brand } \\
\text { B }(70 \%)+30 \mathrm{sec}\end{array}$ & $<0.02$ & $<0.02$ & $<0.02$ & $<0.02$ & $<0.02$ & $<0.02$ & $<0.02$ & $<0.02$ & $<0.02$ & $<0.02$ \\
\hline Epoxy acrylate & $<0.02$ & $<0.02$ & $<0.02$ & $<0.02$ & $<0.02$ & $<0.02$ & $<0.02$ & $<0.02$ & $<0.02$ & $<0.02$ \\
\hline $\begin{array}{l}\text { Epoxy acrylate }+ \text { urethane } \\
\text { acrylate brand B } \\
+ \text { photoinitiator }\end{array}$ & $<0.01$ & $<0.01$ & $<0.01$ & $<0.01$ & $<0.01$ & $<0.01$ & $<0.01$ & $<0.01$ & $<0.01$ & $<0.01$ \\
\hline $\begin{array}{l}\text { Epoxy acrylate + urethane } \\
\text { acrylate brand B }\end{array}$ & $<0.02$ & $<0.02$ & $<0.02$ & $<0.02$ & $<0.02$ & $<0.02$ & $<0.02$ & $<0.02$ & $<0.02$ & $<0.02$ \\
\hline Urethane acrylate brand A & $<0.02$ & $<0.02$ & $<\mathbf{0 . 0 2}$ & 0.05 & $<0.02$ & $<0.02$ & $<0.02$ & $<0.02$ & 1.73 & 0.17 \\
\hline Urethane acrylate brand A UV & $<0.02$ & $<0.02$ & $<0.02$ & 0.04 & $<0.02$ & $<0.02$ & $<0.02$ & $<0.02$ & 1.79 & 0.20 \\
\hline $\begin{array}{l}\text { Urethane acrylate brand A } \\
\text { UV }+0.4 \% \text { photoinitiator }\end{array}$ & $<0.02$ & $<0.02$ & $<0.02$ & $<0.02$ & $<0.02$ & $<0.02$ & $<0.02$ & $<0.02$ & $<0.02$ & $<0.02$ \\
\hline Photoinitiator & $<0.02$ & $<0.02$ & $<0.02$ & $<0.02$ & $<0.02$ & $<0.02$ & $<0.02$ & $<0.02$ & $<0.02$ & $<0.02$ \\
\hline $\begin{array}{c}\text { Polyester }(50 \%)+\text { urethane } \\
\text { acrylate brand B }(50 \%)\end{array}$ & $<0.06$ & $<0.06$ & 60.80 & $<0.06$ & $<0.06$ & 1.17 & $<0.06$ & 12.20 & $<0.06$ & $<0.06$ \\
\hline $\begin{array}{l}\text { Polyester (50\%) + urethane } \\
\text { acrylate brand B (50\%), } \\
\quad+0.4 \% \text { photoinitiator }\end{array}$ & $<0.06$ & $<0.06$ & 38.47 & $<0.06$ & $<0.06$ & 0.81 & $<0.06$ & 7.25 & $<0.06$ & $<0.06$ \\
\hline $\begin{array}{c}\text { Polyester (50\%) + urethane } \\
\text { acrylate brand B (50\%) }\end{array}$ & $<0.03$ & $<0.03$ & $<0.03$ & $<0.03$ & $<0.03$ & $<0.03$ & $<0.03$ & $<0.03$ & $<0.03$ & $<0.03$ \\
\hline Vinyl ester acrylate & 1.07 & $<0.03$ & $<0.03$ & $<0.03$ & $<0.03$ & $<0.03$ & $<0.03$ & $<0.03$ & $<0.03$ & $<0.03$ \\
\hline Vinyl ester acrylate UV & 1.66 & $<0.03$ & $<0.03$ & $<0.03$ & $<0.03$ & $<0.03$ & $<0.03$ & $<0.03$ & $<0.03$ & $<0.03$ \\
\hline $\begin{array}{l}\text { Vinyl ester acrylate UV } \\
+ \text { photoinitiator }\end{array}$ & 0.01 & $<0.01$ & $<0.01$ & $<0.01$ & $<0.01$ & $<0.01$ & $<0.01$ & $<0.01$ & $<0.01$ & $<0.01$ \\
\hline
\end{tabular}


(d)

\begin{tabular}{|c|c|c|c|c|c|c|c|c|c|c|}
\hline \multirow[b]{2}{*}{ Resins } & \multicolumn{10}{|c|}{ Identified compounds cont. } \\
\hline & $\begin{array}{l}\text { Hydrocarbon } \\
\text { (RT 24.54) }\end{array}$ & $\begin{array}{l}\text { Benzyl } \\
\text { acrylate }\end{array}$ & Methoxyphenol & $\begin{array}{c}\text { Ester } \\
\text { (RT 26.6) }\end{array}$ & $\begin{array}{l}\text { Propenoic } \\
\text { acid ester }\end{array}$ & $\begin{array}{c}\mathrm{RT} \\
(26.69)\end{array}$ & $\begin{array}{l}\text { Ester } \\
(26.91)\end{array}$ & $\begin{array}{l}\text { Tertbutil } \\
\text { metyl } \\
\text { phenol }\end{array}$ & (RT 28.88) & Acrylate \\
\hline Epoxyacrylate brand B & 6.46 & 0.92 & 0.89 & $<0.06$ & 2.08 & $<0.06$ & $<0.06$ & $<0.06$ & $<0.06$ & 1.28 \\
\hline $\begin{array}{c}\text { Epoxyacrylate brand B } \\
(50 \%)+\text { urethane acrylate } \\
\text { brand B (50\%) }\end{array}$ & 2.91 & 0.38 & 0.25 & $<0.01$ & 0.80 & $<0.01$ & $<0.01$ & 0.32 & $<0.01$ & 0.82 \\
\hline $\begin{array}{c}\text { Epoxyacrylate brand B } \\
(50 \%)+\text { urethane acrylate } \\
\text { brand B }(50 \%)\end{array}$ & $<0.03$ & 0.06 & 0.01 & $<0.03$ & $<0.03$ & $<0.03$ & $<0.03$ & 0.07 & $<0.03$ & 0.01 \\
\hline Hydroxyethyl metacrylate & $<0.02$ & $<0.02$ & $<0.02$ & $<0.02$ & $<0.02$ & $<0.02$ & 122.83 & $<0.02$ & $<0.02$ & $<0.02$ \\
\hline $\begin{array}{l}\text { Polyester (+hydroxyethyl } \\
\text { methacrylate } 30 \%) \\
\text { + urethane acrylate } \\
\text { brand B }(70 \%)\end{array}$ & 11.35 & $<0.2$ & $<0.2$ & $<0.2$ & 45.58 & $<0.2$ & $<0.2$ & $<0.2$ & $<0.2$ & 1.81 \\
\hline $\begin{array}{l}\text { Polyester + (hydroxyethyl } \\
\text { methacrylate } 30 \%) \\
+ \text { urethane acrylate brand } \\
\text { B }(70 \%)+15 \text { sec }^{\mathrm{a}}\end{array}$ & $<0.02$ & $<0.02$ & $<0.02$ & $<0.02$ & $<0.02$ & $<0.02$ & $<0.02$ & 0.09 & $<0.02$ & $<0.02$ \\
\hline $\begin{array}{l}\text { Polyester (+ hydroxyethyl } \\
\text { methacrylate } 30 \%) \\
+ \text { urethane acrylate brand } \\
\text { B }(70 \%)+30 \mathrm{sec}\end{array}$ & $<0.02$ & $<0.02$ & $<0.02$ & $<0.02$ & $<0.02$ & $<0.02$ & $<0.02$ & 0.05 & $<0.02$ & $<0.02$ \\
\hline Urethane acrylate brand B & $<0.03$ & $<0.03$ & $<0.03$ & $<0.03$ & $<0.03$ & $<0.03$ & $<0.03$ & 0.14 & $<0.03$ & $<0.03$ \\
\hline Epoxy acrylate & $<0.02$ & $<0.02$ & $<0.02$ & $<0.02$ & $<0.02$ & $<0.02$ & $<0.02$ & $<0.02$ & $<0.02$ & $<0.02$ \\
\hline $\begin{array}{l}\text { Epoxy acrylate + urethane } \\
\text { acrylate brand B } \\
\text { photoinitiator }\end{array}$ & $<0.01$ & $<0.01$ & $<0.01$ & $<0.01$ & $<0.01$ & $<0.01$ & $<0.01$ & 0.18 & $<0.01$ & $<0.01$ \\
\hline $\begin{array}{l}\text { Epoxy acrylate + urethane } \\
\text { acrylate brand B }\end{array}$ & $<0.02$ & $<0.02$ & $<0.02$ & $<0.02$ & $<0.02$ & $<0.02$ & $<0.02$ & 0.01 & $<0.02$ & $<0.02$ \\
\hline Urethane acrylate brand A & $<0.02$ & $<0.02$ & $<0.02$ & $<0.02$ & $<0.02$ & $<0.02$ & $<0.02$ & $<0.02$ & 0.44 & $<0.02$ \\
\hline Urethane acrylate brand A UV & $<0.02$ & $<0.02$ & $<0.02$ & $<0.02$ & $<0.02$ & $<0.02$ & $<0.02$ & $<0.02$ & 0.53 & $<0.02$ \\
\hline $\begin{array}{l}\text { Urethane acrylate brand A } \\
\text { UV }+0.4 \% \text { photoinitiator }\end{array}$ & $<0.02$ & $<0.02$ & $<0.02$ & $<0.02$ & $<0.02$ & $<0.02$ & $<0.02$ & $<0.02$ & $<0.02$ & $<0.02$ \\
\hline Photoinitiator & $<0.02$ & $<0.02$ & $<0.02$ & $<0.02$ & $<0.02$ & $<0.02$ & $<0.02$ & $<0.02$ & $<0.02$ & $<0.02$ \\
\hline $\begin{array}{l}\text { Polyester }(50 \%)+\text { urethane } \\
\text { acrylate brand B (50\%) }\end{array}$ & $<0.06$ & $<0.06$ & $<0.06$ & 28.93 & $<0.06$ & 69.63 & $<0.06$ & $<0.06$ & $<0.06$ & $<0.06$ \\
\hline $\begin{array}{l}\text { Polyester }(50 \%)+\text { urethane } \\
\text { acrylate brand B (50\%) } \\
\text { + } 0.4 \% \text { photoinitiator }\end{array}$ & $<0.06$ & $<0.06$ & $<0.06$ & 19.73 & $<0.06$ & 41.11 & $<0.06$ & $<0.06$ & $<0.06$ & $<0.06$ \\
\hline $\begin{array}{l}\text { Polyester }(50 \%)+\text { urethane } \\
\text { acrylate brand B (50\%) }\end{array}$ & $<0.03$ & $<0.03$ & $<0.03$ & 0.04 & $<0.03$ & $<0.03$ & $<0.03$ & $<0.03$ & $<0.03$ & $<0.03$ \\
\hline Vinyl ester acrylate & $<0.03$ & $<0.03$ & $<\mathbf{0 . 0 3}$ & $<0.03$ & $<0.03$ & $<0.03$ & $<0.03$ & $<0.03$ & $<0.03$ & $<0.03$ \\
\hline Vinyl ester acrylate UV & $<0.03$ & $<0.03$ & $<0.03$ & $<0.03$ & $<0.03$ & $<0.03$ & $<0.03$ & $<0.03$ & $<0.03$ & $<0.03$ \\
\hline $\begin{array}{l}\text { Vinyl ester acrylate UV } \\
\text { + photoinitiator }\end{array}$ & $<0.01$ & $<0.01$ & $<0.01$ & $<0.01$ & $<0.01$ & $<0.01$ & $<0.01$ & $<0.01$ & $<0.01$ & $<0.01$ \\
\hline
\end{tabular}


(e)

\begin{tabular}{|c|c|c|c|c|c|c|}
\hline \multirow[b]{2}{*}{ Resins } & \multicolumn{6}{|c|}{ Identified compounds cont. } \\
\hline & $\begin{array}{c}\text { Propenoic acid } \\
\text { ester } \\
\text { (RT 30.57) }\end{array}$ & $\begin{array}{l}\text { Butylene glycol } \\
\text { dimethacrylate }\end{array}$ & BHT & BHA & Acrylate & Cyclodecane \\
\hline Epoxyacrylate brand B & 2.68 & $<0.06$ & $<0.06$ & $<0.06$ & $<0.06$ & 1.05 \\
\hline $\begin{array}{c}\text { epoxyacrylate brand B } \\
(50 \%)+\text { urethane acrylate } \\
\text { brand B (50\%) }\end{array}$ & 0.71 & $<0.01$ & 18.75 & $<0.01$ & $<0.01$ & 0.34 \\
\hline $\begin{array}{c}\text { Epoxy acrylate brand B } \\
(50 \%)+\text { urethane acrylate } \\
\text { brand B }(50 \%)\end{array}$ & 0.01 & $<0.03$ & 1.41 & $<0.03$ & $<0.03$ & 0.01 \\
\hline Hydroxyethyl metacrylate & $<0.02$ & $<0.02$ & 1.68 & $<0.02$ & $<0.02$ & $<0.02$ \\
\hline $\begin{array}{l}\text { Polyester (+hydroxyethyl } \\
\text { methacrylate } 30 \%)(30 \%) \\
+ \text { urethane acrylate brand } \\
\text { B }(70 \%),+0.5 \text { one }\end{array}$ & $<0.2$ & $<0.2$ & 94.17 & $<0.2$ & $<0.2$ & $<0.2$ \\
\hline $\begin{array}{l}\text { Polyester (+hydroxyethyl } \\
\text { methacrylate } 30 \%)(30 \%) \\
\text { + urethane acrylate brand } \\
\text { B }(70 \%)+15 \text { sec }^{\mathrm{a}}\end{array}$ & $<0.02$ & $<0.02$ & 2.25 & $<0.02$ & $<0.02$ & $<0.02$ \\
\hline $\begin{array}{c}\text { Polyester (+hydroxyethyl } \\
\text { methacrylate } 30 \%)(30 \%) \\
\text { + urethane acrylate brand } \\
\text { B }(70 \%),+30 \sec ^{\mathrm{a}}\end{array}$ & $<0.02$ & $*$ & 1.74 & $<0.02$ & $<0.02$ & $<0.02$ \\
\hline Urethane acrylate brand B & $<0.03$ & $<0.03$ & 4.88 & $<0.03$ & $<0.03$ & $<0.03$ \\
\hline Epoxy acrylate & $<0.02$ & $<0.02$ & 0.30 & 0.48 & $<0.02$ & $<0.02$ \\
\hline $\begin{array}{l}\text { Epoxy acrylate + urethane } \\
\text { acrylate brand B } \\
\text { + photoinitiator }\end{array}$ & $<0.01$ & $<0.01$ & 5.08 & 0.11 & $<0.01$ & $<0.01$ \\
\hline $\begin{array}{l}\text { Epoxy acrylate + urethane } \\
\text { acrylate brand B }\end{array}$ & $<0.02$ & $<0.02$ & 0.30 & $<0.02$ & $<0.02$ & $<0.02$ \\
\hline Urethane acrylate brand A & 2.44 & $<0.02$ & $<0.02$ & 1.01 & $<0.02$ & $<0.02$ \\
\hline Urethane acrylate brand A UV & 2.71 & $<0.02$ & $<0.02$ & 1.20 & $<0.02$ & $<0.02$ \\
\hline $\begin{array}{l}\text { Urethane acrylate brand A } \\
\text { UV }+0.4 \% \text { photoinitiator }\end{array}$ & $<0.02$ & $<0.02$ & 0.08 & 0.23 & $<0.02$ & $<0.02$ \\
\hline Photoinitiator & $<0.02$ & $<0.02$ & $<0.02$ & $<0.02$ & $<0.02$ & $<0.02$ \\
\hline $\begin{array}{l}\text { Polyester }(50 \%)+\text { urethane } \\
\text { acrylate brand B (50\%) }\end{array}$ & $<0.06$ & $<0.06$ & 0.12 & $<0.06$ & $<0.06$ & $<0.06$ \\
\hline $\begin{array}{l}\text { Polyester }(50 \%)+\text { urethane } \\
\text { acrylate brand B (50\%) } \\
+0.4 \% \text { photoinitiator }\end{array}$ & $<0.06$ & $<0.06$ & $<0.06$ & $<0.06$ & $<0.06$ & $<0.06$ \\
\hline $\begin{array}{l}\text { Polyester (50\%) + urethane } \\
\text { acrylate brand B (50\%) }\end{array}$ & $<0.03$ & $<0.03$ & $<0.03$ & $<0.03$ & $<0.03$ & $<0.03$ \\
\hline Vinyl ester acrylate & $<\mathbf{0 . 0 3}$ & 11.16 & 0.81 & $<0.03$ & 3.90 & $<0.03$ \\
\hline Vinyl ester acrylate UV & $<0.03$ & 6.55 & 0.91 & $<0.03$ & 2.69 & $<0.03$ \\
\hline $\begin{array}{l}\text { Vinyl ester acrylate UV } \\
+ \text { photoinitiator }\end{array}$ & $<0.01$ & $<0.01$ & $<0.01$ & $<0.01$ & 0.02 & $<0.01$ \\
\hline
\end{tabular}

atime of UV curing; " not measured. 
Table 4. VOCs toxicological parameters.

\begin{tabular}{ccc}
\hline & \multicolumn{2}{c}{ Parameters } \\
\cline { 2 - 3 } VOCs & RfDa and ADIb (mg/kg day) & Daily dose (mg day) \\
Styrene & $0.2^{\mathrm{a}}$ & 12 \\
Toluene & $0.08^{\mathrm{a}}$ & 4.8 \\
BHA & $1^{\mathrm{b}}$ & 60 \\
BHT & $0.2^{\mathrm{b}}$ & 15 \\
Xylenes & $0.2^{\mathrm{a}}$ & 12 \\
Benzaldehyde & $0.1^{\mathrm{a}}$ & 6 \\
\hline
\end{tabular}

${ }^{\mathrm{a}} \mathrm{RfD}$ (Reference Dose); ${ }^{\mathrm{b}} \mathrm{ADI}$ (Acceptable Daily Intake).

Table 5. BPA concentration expressed as ng/g of analyzed resin.

\begin{tabular}{|c|c|}
\hline Resins & BPA (ng/g resin) \\
\hline $\begin{array}{c}\text { Polyester + hydroxyethyl metacrylate }(30 \%)+\text { urethane acrylate } \\
\text { brand B }(70 \%)+0.5 \% \text { photoinitiator }\end{array}$ & 122.3 \\
\hline Hydroxyethyl metacrylate & 288.3 \\
\hline $\begin{array}{l}\text { Polyester (50\%) + urethane acrylate brand B (50\%) } \\
+0.4 \% \text { photoinitiator }\end{array}$ & 105.9 \\
\hline Epoxy acrylate brand B & $<2$ \\
\hline $\begin{array}{c}\text { Polyester + hydroxyethyl metacrylate }(30 \%)+\text { urethane acrylate } \\
\text { brand B (70\%), curing time } 30 \mathrm{sec}\end{array}$ & 48.6 \\
\hline $\begin{array}{c}\text { Polyester + hydroxyethyl metacrylate (30\%) + urethane acrylate } \\
\text { brand B (70\%), curing time } 15 \mathrm{sec}\end{array}$ & 179.0 \\
\hline Polyester (50\%) + urethane acrylate brand B (50\%) & 355.3 \\
\hline Epoxy acrylate + urethane acrylate brand B & 51.2 \\
\hline Vinyl ester acrylate & 151.7 \\
\hline Epoxy acrylate brand B (50\%) + urethane acrylate brand B (50\%) & $<2$ \\
\hline
\end{tabular}

Table 6. Results of VOCs analysis in the migration test in test pipe. Resin results are reported as $\mu \mathrm{g} / \mathrm{g}$ and samples of water as ng/L.

\begin{tabular}{|c|c|c|c|c|c|c|c|c|c|c|}
\hline \multirow[b]{2}{*}{ Samples } & \multicolumn{10}{|c|}{ Identified compound } \\
\hline & Naphthalene & Benzothiazole & $\begin{array}{l}\text { Propenoic } \\
\text { acid ester }\end{array}$ & $\begin{array}{l}\text { Propenoic } \\
\text { acid ester }\end{array}$ & $\begin{array}{c}\text { Methyl } \\
\text { naphthalene }\end{array}$ & Quinoline & BHT & $\begin{array}{c}\text { 1,4-butylene } \\
\text { glycol } \\
\text { dimethacrylate }\end{array}$ & $\begin{array}{c}\text { Diethylene } \\
\text { glycol } \\
\text { dimethacrylate }\end{array}$ & $\begin{array}{l}\text { Propenoic } \\
\text { acid ester }\end{array}$ \\
\hline $\begin{array}{l}\text { Vinyl ester } \\
\text { acrylate }\end{array}$ & $<0.02$ & $<0.02$ & 5.01 & 4.13 & $<0.02$ & $<0.02$ & 0.92 & 44.72 & 6.52 & $<0.02$ \\
\hline $\begin{array}{l}\text { Aqueduct } \\
\text { water }\end{array}$ & $<0.01$ & $<0.01$ & $<0.01$ & $<0.01$ & $<0.01$ & $<0.01$ & $<0.01$ & 0.02 & $<0.01$ & 0.02 \\
\hline Pipe water & 0.04 & 0.08 & $<0.01$ & $<0.01$ & 0.01 & 0.04 & $<0.01$ & 0.12 & $<0.01$ & $<0.01$ \\
\hline
\end{tabular}




\section{Conclusions}

A complex approach is presented to identify possible contaminants release in drinking water from new materials and to assess their effects for human health. The use of candidate new ISO standard methods for GC/MS and high resolution HPLC/MS instrumentation, allowed identification and quantitative analysis of residues in materials and in drinking water in a field migration experiment.

A number of monomers and solvents have been identified both in polymer samples and in water sample after an in field prototype relining experiment.

In this study, both high resolution HPLC/MS and GC/MS analysis showed negligible release of toxic substances with concentrations that are lower than safety values. The solvents released by the coating of the pipe, even after the contact of 24 hours with water, appear to be lower than the limit of detection (generally $10 \mathrm{ppb}$ ). The butylene glycol methacrylate is present in concentrations of $0.12 \mathrm{ppm}$ but there are not many available toxicological information relating to this compound. According to the QSAR models, this compound is not carcinogenic, not mutagenic, is a skin sensitizer and is biodegradable.

With regard to the BPA, its concentration is lower than the detection limit in the pipe water after one day of migration field test. However, given the attention that is given in EU and US to this endocrine disruptor, it is recommended to use resins with non detectable BPA.

\section{Acknowledgements}

The Regional Project “Safe Pipe” Bando ATP “Regione Lombardia-Nuovi Materiali” is gratefully acknowledged for financial support of this work.

\section{References}

[1] MM Metropolitana Milanese SPA (2012) Bilancio di sostenibilità del Servizio Idrico Integrato. http://www.metropolitanamilanese.it/pub/page/it/MM/bilancio_sociale

[2] ChemSec Intenational Chemical Secretariat (2013) BPA Found in Tap Water from Relined Water Pipes in Sweden. http://www.chemsec.org/news/news-2013/january-march/1144-bpa-found-in-tap-water

[3] Martinez Bueno, M.J., Uclés, S., Hernando, M.D., Davoli, E. and Fernandez-Alba, A.R. (2011) Evaluation of Selected Ubiquitous Contaminants in the Aquatic Environment and Their Transformation Products. A Pilot Study of Their Removal from a Sewage Treatment Plant. Water Research, 45, 2331-2341. http://dx.doi.org/10.1016/j.watres.2011.01.011

[4] Ziaee, S. and Palmese, G.R. (1999) Effects of Temperature on Cure Kinetics and Mechanical Properties of vinyl-Ester Resins. Journal of Polymer Science Part B: Polymer Physics, 37, 725-744. http://dx.doi.org/10.1002/(SICI)1099-0488(19990401)37:7<725::AID-POLB23>3.0.CO;2-E

[5] Weiss, K.D. (1997) Paint and Coatings: A Mature Industry in Transition. Progress in Polymer Science, 22, $203-245$. http://dx.doi.org/10.1016/S0079-6700(96)00019-6

[6] Kurochkin, S.A., Silant'ev, M.A., Perepelitsyna, E.O. and Grachev, V.P (2013) Molecular Oxygen as a Regulator of Primary Chain Length of Branched Polymers Formed in 3D Radical Polymerization. Oxidative Polymerization of Styrene. Polymer, 54, 31-42. http://dx.doi.org/10.1016/j.polymer.2012.11.026

[7] Brent Strong, A. (2008) Fundamentals of Composites Manufacturing: Materials, Methods and Applications. Society of Manufacturing Engineers. Dearborn, Michigan.

[8] La Scala, J.J., Sands, J.M. and Palmese, G.R. (2004) Liquid Resins with Low VOC Emissions. Army Research laboratory, Aberdeen Proving Ground, MD. Weapons and Materials Research Directorate. Technical Report.

[9] Alavi, S., Sabu, T., Sandeep, K.P., Kalarikkal, N., Varghese, J. and Yaragalla, S. (2015) Polymers for Packaging Applications. Apple Academic Press, Toronto. 